\title{
Opioid Receptor-Dependent Sex Differences in Synaptic Plasticity in the Hippocampal Mossy Fiber Pathway of the Adult Rat
}

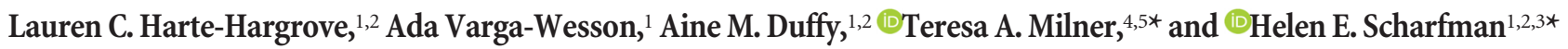 \\ ${ }^{1}$ The Nathan Kline Institute for Psychiatric Research, Center of Dementia Research, Orangeburg, New York 10962, New York University, Langone Medical \\ Center, Departments of ${ }^{2}$ Child and Adolescent Psychiatry, and ${ }^{3}$ Physiology and Neurosci, Psychiatry, New York, New York 10016, ${ }^{4}$ Weill Cornell Medical \\ College, Brain and Mind Research Institute, New York, New York 10065, and ${ }^{5}$ The Rockefeller University, Laboratory of Neuroendocrinology, New York, \\ New York 10065
}

\begin{abstract}
The mossy fiber (MF) pathway is critical to hippocampal function and influenced by gonadal hormones. Physiological data are limited, so we asked whether basal transmission and long-term potentiation (LTP) differed in slices of adult male and female rats. The results showed small sex differences in basal transmission but striking sex differences in opioid receptor sensitivity and LTP. When slices were made from females on proestrous morning, when serum levels of $17 \beta$-estradiol peak, the nonspecific opioid receptor antagonist naloxone $(1 \mu \mathrm{M})$ enhanced MF transmission but there was no effect in males, suggesting preferential opioid receptor-dependent inhibition in females when $17 \beta$-estradiol levels are elevated. The $\mu$-opioid receptor (MOR) antagonist Cys2,Tyr3,0rn5,Pen7-amide (CTOP; $300 \mathrm{nм}$ ) had a similar effect but the $\delta$-opioid receptor (DOR) antagonist naltrindole (NTI; $1 \mu \mathrm{M}$ ) did not, implicating MORs in female MF transmission. The $\mathrm{GABA}_{\mathrm{B}}$ receptor antagonist saclofen $(200 \mu \mathrm{M})$ occluded effects of CTOP but the $\mathrm{GABA}_{\mathrm{A}}$ receptor antagonist bicuculline $(10 \mu \mathrm{M})$ did not. For LTP, a low-frequency (LF) protocol was used because higher frequencies elicited hyperexcitability in females. Proestrous females exhibited LF-LTP but males did not, suggesting a lower threshold for synaptic plasticity when $17 \beta$-estradiol is elevated. NTI blocked LF-LTP in proestrous females, but CTOP did not. Electron microscopy revealed more DOR-labeled spines of pyramidal cells in proestrous females than males. Therefore, we suggest that increased postsynaptic DORs mediate LF-LTP in proestrous females. The results show strong MOR regulation of MF transmission only in females and identify a novel DOR-dependent form of MF LTP specific to proestrus.
\end{abstract}

Key words: area CA3; estrous cycle; hippocampus; long-term potentiation; opiate; sex differences

\section{Introduction}

There are numerous sex differences in hippocampal-dependent behavior (Maren et al., 1994; Astur et al., 1998; Jonasson, 2005), but the mechanisms are unclear. One hypothesis to explain sex differences has come from studies of a critical pathway, the mossy fibers (MFs), which are the axons of dentate gyrus granule cells that project to the hilus and CA3 (Amaral et al., 2007; Jaffe and Gutiérrez, 2007; Sindreu et al., 2011). The MFs are relevant because of high concentrations of receptors for estrogens and an-

\footnotetext{
Received Feb. 25, 2014; revised Nov. 18, 2014; accepted Dec. 8, 2014.

Author contributions: L.C.H.-H., T.A.M., and H.E.S. designed research; L.C.H.-H., A.V.-W., A.M.D., T.A.M., and H.E.S. performed research; L.C.H.-H., A.V.-W., and H.E.S. analyzed data; L.C.H.-H., T.A.M., and H.E.S. wrote the paper.

This work was supported by NIH Grants R01 DA-008259, T32 MH-097763, and the New York State Office of Mental Health. We thank Dr Neil MacLusky and Dr Charles Schroeder for discussion, and Andreina Gonzalez for technical assistance.

The authors declare no competing financial interests.

*T.A.M. and H.E.S. contributed equally to this work.

Correspondence should be addressed to Dr Helen E. Scharfman, The Nathan Kline Institute for Psychiatric Research, Center of Dementia Research, 140 Old Orangeburg Road, Building 35, Orangeburg, NY 10962. E-mail: hscharfman@nki.rfmh.org.

DOI:10.1523/JNEUROSCI.0820-14.2015

Copyright $\odot 2015$ the authors $\quad 0270-6474 / 15 / 351723-16 \$ 15.00 / 0$
}

drogens (McEwen and Milner, 2007), remarkable plasticity (Jaffe and Gutiérrez, 2007), and regulation by gonadal hormones (Harte-Hargrove et al., 2013; Scharfman and MacLusky, 2013).

In females, systemic $17 \beta$-estradiol administration to ovariectomized rats increases the response to MF stimulation in hippocampal slices, and repetitive population spikes (hyperexcitability) can be evoked by low-frequency (LF) stimulation (Scharfman et al., $2003,2007,2013)$. Similar effects occur in slices that are prepared from animals which are killed when serum levels of $17 \beta$-estradiol peak, midmorning of proestrus (Scharfman et al., 2003). In males, androgens appear to antagonize this effect because hyperexcitability occurs after castration and is prevented by testosterone (Skucas et al., 2013). In addition, androgens normally appear to limit MF long-term potentiation (LTP) because MF LTP is enhanced after castration (Skucas et al., 2013). These studies suggest that, in males, androgens reduce the risk of hyperexcitability, but at the "price" of decreased MF plasticity (Scharfman and MacLusky, 2014; Skucas et al., 2013). Conversely, $17 \beta$-estradiol in females seems to induce hyperexcitability in CA3, which might be the price for increased plasticity, but it has not been examined. Therefore, we made direct comparisons using hippocampal slices of males and females. Initial studies showed that the typical high- 
frequency trains used to induce LTP in males led to hyperexcitability in slices of female rats, which is similar to previous studies (Warren et al., 1995), so LTP was induced with three lowfrequency trains (paired pulses, $40 \mathrm{~ms}$ apart, $1 \mathrm{~Hz}$; Scharfman et al., 2003). A similar procedure (paired pulses, $40 \mathrm{~ms}$ apart, $1 \mathrm{~Hz}$, 30-120 s duration) has been shown to elicit MF LTP in 15- to 21-d-old males (Frausto et al., 2011).

We also addressed opioid peptide regulation, because opioid peptides (enkephalins and dynorphin) are present in MFs, and opioid receptors ( $\mu$-opioid receptors, MORs; $\delta$-opioid receptors, DORs) are present in CA3 (for review, see Drake et al., 2007). Moreover, there are sex differences and gonadal steroid regulation of opioid peptide levels and MOR/DOR trafficking (TorresReveron et al., 2008, 2009a,b; Williams et al., 2011b; Burstein et al., 2013; Milner et al., 2013; Pierce et al., 2014). Finally, male LTP is facilitated by MORs on MF terminals (Martin, 1983; Derrick et al., 1991, 1992; Jin and Chavkin, 1999; Jamot et al., 2003).

The results demonstrate that there are sex differences in MF transmission and LTP. Basal transmission was greater in males than females, although this difference was small and variable. On the other hand, there was a striking MOR sensitivity of basal transmission and DOR-dependent LTP in proestrous females.

\section{Materials and Methods}

\section{Animals}

Animal use met NIH guidelines and was approved by the Institutional Animal Care and Use Committee at The Nathan Kline Institute (electrophysiology) or Weill Cornell Medical College (electron microscopy; EM). Adult (2- to 4-month-old) male and female Sprague-Dawley rats (Charles River) were housed with the same sex, 2-4/cage, with a $12 \mathrm{~h}$ light/dark cycle and ad libitum access to water and food (Purina Lab Diet 5001 chow; W.F. Fisher).

\section{Determination of estrous cycle stage}

To determine estrous cycle stages in female rats, vaginal cytology was conducted daily for at least two estrous cycles between the hours of 9:00 A.M. and 11:00 A.M. Rats were used for slice experiments only if they exhibited $\geq 2$ consecutive 4 -d long estrous cycles, with the pattern of cytology consistent with the known pattern of hormonal secretion in the female Sprague Dawley rat (Freeman, 1984). This pattern is associated with a $2 \mathrm{~d}$ period called diestrus (the first day called diestrus- 1 or metestrus, and the second day referred to as diestrus-2), followed by a day called proestrus, and another day called estrus. During diestrus-2, serum levels of $17 \beta$-estradiol slowly rise, and on proestrous morning they surge to reach their peak approximately midmorning; in the afternoon, serum levels return to low levels until the next cycle (Freeman, 1984). On the day of electrophysiological recording from hippocampal slices, females were first examined to confirm the cycle stage by vaginal cytology, and then killed between 10:00 and 11:00 A.M. (the start of the light cycle was 7:00 A.M.). For anatomical studies, rats were used if they exhibited two consecutive regular estrous cycles; final estrous cycle stage was taken when rats were killed between 9:00 A.M. and 1:00 P.M.

\section{Electrophysiology}

Slice preparation. Following isoflurane anesthesia, rats were decapitated, brains were quickly removed, hemisected, and placed in ice-cold $\left(4^{\circ} \mathrm{C}\right)$ oxygenated $\left(95 \% \mathrm{O}_{2} / 5 \% \mathrm{CO}_{2}\right)$ sucrose-based artificial CSF [ACSF; containing the following (in $\mathrm{mM}$ ): 252 sucrose, $3.5 \mathrm{KCl}, 2.4 \mathrm{CaCl}_{2}, 2.0$ $\mathrm{MgSO}_{4}, 26 \mathrm{NaHCO}_{3}, 1.25 \mathrm{NaH}_{2} \mathrm{PO}_{4}, 10 \mathrm{D}$-glucose] for $\sim 60 \mathrm{~s}$. Horizontal slices ( $400 \mu \mathrm{m}$ thick) were cut from the middle third of the hippocampus in ice-cold ACSF (Vibroslice; Campden Instruments). Slices were transferred to oxygenated ACSF at room temperature for $\sim 5 \mathrm{~min}$ and then placed in a recording chamber (Scharfman et al., 2001) at $30-$ $32^{\circ} \mathrm{C}$ (PTCO3, Scientific Systems Design) where sucrose-ACSF was perfused (1-2 $\mathrm{ml} / \mathrm{min}$; Minipuls 2, Gilson) so that slices were immersed except for the upper surfaces. After $30 \mathrm{~min}, \mathrm{NaCl}$-based ACSF
(126 NaCl instead of 252 sucrose) was used. Recordings began at least 30 min later.

Recording and stimulation. Standard recording procedures were used (Skucas et al., 2011; Skucas et al., 2013). Electrodes were made from capillary-filled, borosilicate glass ( $1.0 \mathrm{~mm}$ outer diameter, $0.75 \mathrm{~mm}$ inner diameter; World Precision Instruments) pulled horizontally (P87, Sutter Instruments), and placed in stratum lucidum of CA3b to record MF field EPSPs (fEPSPs). Measures that were taken to ensure that MFs were stimulated selectively are described previously (Skucas et al., 2013). In brief, a Teflon-coated monopolar electrode (diameter, $75 \mu \mathrm{m}$, including Teflon) was placed on the slice surface within the subgranular zone of the dentate gyrus, near the crest (i.e., where the superior and inferior blades meet). Recordings were then sampled from the $\mathrm{CA} 3 \mathrm{~b}$ region throughout stratum lucidum to find the location where the maximal fEPSP was located. Only fEPSPs with a latency consistent with monosynaptic activation $(<4$ $\mathrm{ms}$ ) and other criteria (Skucas et al., 2013) were used. Recordings were amplified (Axoclamp 2B, Molecular Devices), digitized (Digidata 1440, Molecular Devices), acquired and analyzed using pClamp (v10.3; Molecular Devices).

LTP. LTP was tested if the fEPSP slope was stable, defined by fEPSP amplitudes that differed from the mean of the $10 \mathrm{~min}$ baseline period by $\pm 5 \%$ or less. Stimuli during the baseline period and following the induction of LTP were half-maximal stimuli at $0.05 \mathrm{~Hz}$.

LTP was induced using a protocol that minimized hyperexcitability after the trains of stimuli. Hyperexcitability is defined here as repetitive field potentials following a single stimulus (Scharfman et al., 2003). After as few as four pairs of stimuli at frequencies as low as $1 \mathrm{~Hz}$, repetitive field potentials were sometimes followed by spreading depression (SD), which begins with a large synchronous depolarization of pyramidal cells that is reflected extracellularly by a large DC shift and a subsequent lack of response to stimulation for seconds to minutes (Scharfman, 1997; Rogawski, 2012; Skucas et al., 2013). It has been demonstrated that hyperexcitability and SD occurs preferentially in females when serum levels of $17 \beta$-estradiol are high, such as the proestrous female rat (Scharfman et al., 2003; Eikermann-Haerter et al., 2009; Adámek and Vyskočil, 2011; Harte-Hargrove et al., 2013) or in the $24 \mathrm{~h}$ following the $17 \beta$-estradiol surge (Scharfman et al., 2003; Harte-Hargrove et al., 2013).

For the LF protocol to induce LTP, three trains were delivered. Each train was 10 pairs of half-maximal stimuli ( $40 \mathrm{~ms}$ interstimulus interval) at $1 \mathrm{~Hz}$ (total duration, $10 \mathrm{~s}$ ). This pattern of stimulation was previously shown to distinguish MF transmission in the female rat on proestrous morning from diestrous-1 morning (Scharfman et al., 2003). Some slices showed potentiation after even one stimulus train (Scharfman, unpublished), suggesting it would be an effective stimulation protocol to study synaptic plasticity. Indeed, in young male rats, a similar procedure elicited robust LTP with $1 \mathrm{~Hz}$ pairs of pulses at $40 \mathrm{~ms}$ interstimulus intervals noted as being particularly effective (Frausto et al., 2011). For the purposes of the present study, we refer to the LTP after our protocol as LF-LTP. This terminology is distinct from the term "PP-LTP" of Frausto et al. (2011), because they used a slightly different procedure (1 train lasting $30-120 \mathrm{~s})$.

Pharmacology. Naloxone hydrochloride (naloxone; Sigma-Aldrich), D-Phe-Cys-Tyr-D-Trp-Orn-Thr-Pen-Thr- $\mathrm{NH}_{2}$ (CTOP; R\&D Systems) and naltrindole hydrochloride (NTI; R\&D Systems) were dissolved in a $0.9 \%$ saline solution to create a $1 \mathrm{~m}$ stock solution and stored at $4^{\circ} \mathrm{C}$ until use. Stock solutions were diluted in NaCl-ACSF on the day of the experiment to reach their final concentration (naloxone, $1 \mu \mathrm{M}$; CTOP, $300 \mathrm{nM}$; NTI, $1 \mu \mathrm{M}$ ). The doses were chosen because they have been used to examine maximal effects in hippocampal slices at opioid receptors while maintaining specificity (Watson and Lanthorn, 1993; Xie and Lewis, 1995; Jin and Chavkin, 1999; McQuiston, 2007).

The $\mathrm{GABA}_{\mathrm{A}}$ receptor antagonist (-) bicuculline methiodide (BMI; Sigma-Aldrich) was dissolved in $0.9 \% \mathrm{NaCl}$ at $10 \mathrm{~mm}$ and stored at $-20^{\circ} \mathrm{C}$ until use. When BMI was used, $4 \mathrm{mM} \mathrm{MgCl}_{2}\left(\right.$ total $\left[\mathrm{Mg}^{2+}\right]_{\mathrm{o}}, 6$ $\mathrm{mm}$ ) was added to block epileptiform activity. The $\mathrm{GABA}_{\mathrm{B}}$ receptor antagonist saclofen (Tocris Biosciences) was dissolved in distilled $\mathrm{H}_{2} \mathrm{O}$ $\left(\mathrm{dH}_{2} \mathrm{O}\right)$ at $100 \mathrm{~mm}$ and stored at $4^{\circ} \mathrm{C}$.

Data analysis. fEPSPs were quantified using pClamp and were described in detail previously (Skucas et al., 2011). No more than two slices 
per rat were used. fEPSP slope was defined as the maximal slope of the rising phase of the fEPSP. fEPSP amplitude was defined as the difference between the average prestimulus potential (between 1 and $5 \mathrm{~ms}$ before the stimulus) and the fEPSP peak. fEPSP duration was quantified by calculating half-duration, the time from the midpoint of the stimulus artifact to the point where the fEPSP decayed to half of its maximal amplitude. Area under the curve (area) was defined as the area between the fEPSP and a horizontal line at $0 \mathrm{mV}$ (Skucas et al., 2011). The starting point for this measurement was the onset of the fiber volley and the termination point was $35 \mathrm{~ms}$ after the stimulus, when most fEPSPs had ended. Latency to the fEPSP peak and fiber volley peak were measured from midpoint of the stimulus artifact. Fiber volley amplitude was defined as the difference between the onset of the fiber volley and the peak of the fiber volley. Fiber volley incidence was assessed using maximal stimulation strength to standardize the stimulus across slices, and increase the chance that a fiber volley would be detected if it were present. Paired-pulse facilitation (PPF) was defined as the ratio of the second fEPSP slope relative to the first fEPSP slope, evoked by two identical stimuli. For post-tetanic potentiation (PTP) and LTP, fEPSP slopes were normalized to the average of the $10 \mathrm{~min}$ period before LTP induction (the baseline). PTP was defined by the first response following LTP induction ( $60 \mathrm{~s}$ after the last stimulus of the train). LTP amplitude was defined as the mean of the last 10 responses, which were recorded 35-45 min following the first LTP train.

\section{Immuno-EM}

Antibody specificity. A rabbit polyclonal antibody against N-terminal amino acid (aa) 3-17 of the DOR was purchased originally from Millipore Bioscience Research Reagents. The specificity of this antibody has been previously shown by Western blot and absence of labeling in sections incubated in preimmune sera or in preadsorption controls (Commons and Milner, 1997; Persson et al., 2000; Persson et al., 2005). This antibody has been used in our previous light and EM studies (Commons and Milner, 1997; Williams et al., 2011a). Moreover, our previous studies have shown that the Millipore Bioscience Research Reagents DOR antibody yields an identical pattern of labeling in the hippocampus as a DOR antibody raised in guinea pigs against aa 34-48 (Commons and Milner, 1997).

Tissue preparation. Rats were deeply anesthetized with sodium pentobarbital (150 mg/kg, i.p.) and perfused sequentially through the ascending aorta with: (1) $10-15 \mathrm{ml} 0.9 \%$ saline containing $2 \%$ heparin; (2) 50 $\mathrm{ml}$ of $3.75 \%$ acrolein and $2 \%$ paraformaldehyde in $0.1 \mathrm{M}$ phosphate buffer (PB), pH 7.4; and (3) $200 \mathrm{ml}$ of 2\% paraformaldehyde in PB. After perfusion, brains were cut into $5 \mathrm{~mm}$ coronal blocks using a brain mold (Activational Systems), postfixed in 2\% paraformaldehyde in PB for 30 $\mathrm{min}$, and then placed into PB. Coronal sections ( $40 \mu \mathrm{m}$ thick) through the hippocampus were cut on a vibrating microtome (Leica Microsystems) and then stored in cryoprotectant solution (30\% sucrose and $30 \%$ ethylene glycol in $\mathrm{PB}$ ) at $-20^{\circ} \mathrm{C}$. Before immunocytochemical processing, sections were rinsed in $\mathrm{PB}$. So that relative comparisons of DORlabeling could be made between groups, sections were coded with hole punches and pooled into a single container to ensure identical processing (Pierce et al., 1999). Sections were incubated in sodium borohydride (1\% in $\mathrm{PB}$ ) for $30 \mathrm{~min}$ and rinsed in $\mathrm{PB}$.

Tissue processing. Sections were labeled for DOR using pre-embedding immunogold as described previously (Williams et al., 2011a). In brief, sections were incubated in the DOR antibody (1:5000 dilution) in $0.1 \%$ bovine serum albumin and Tris-buffered saline (TS), $\mathrm{pH}$ 7.6, for $1 \mathrm{~d}$ at room temperature and $4 \mathrm{~d}$ at $4{ }^{\circ} \mathrm{C}$. Sections were rinsed in TS and incubated in donkey anti-rabbit IgG-conjugated to $1 \mathrm{~nm}$ gold particles [1:50, Electron Microscopy Sciences (EMS)] at $4^{\circ} \mathrm{C}$ overnight. Sections were rinsed in PBS, postfixed in 2\% glutaraldehyde in PBS for $10 \mathrm{~min}$, and rinsed in PBS followed by $0.2 \mathrm{M}$ sodium citrate buffer, $\mathrm{pH}$ 7.4. The conjugated gold particles were enhanced by reaction in a silver solution (RPN491 Silver Enhance kit, GE Healthcare) for $6 \mathrm{~min}$.

Sections were fixed in $2 \%$ osmium tetroxide for $1 \mathrm{~h}$ followed by PB rinses and dehydration in increasing concentrations of ethanol and propylene oxide before being embedded in Embed 812 (EMS; Milner and Drake, 2001). The CA3b region ( $\sim 3.6 \mathrm{~mm}$ from bregma; Swanson,
1992) was identified in flat-embedded plastic sections under a light microscope, glued onto plastic chucks, and then trimmed to a 1-mm-wide trapezoid. Ultra thin sections ( $70-72 \mathrm{~nm}$ thick) from CA3b were cut on a Leica UCT ultratome through the tissue-plastic interface as this region has optimal antibody penetration (Milner et al., 2011). Thin sections were collected on 400-mesh thin-bar copper grids (EMS) amd the grids were counterstained with uranyl acetate and Reynolds lead citrate.

Data analysis. A person who was blind to experimental group performed all data collection and analyses. Sections were examined on a CM10 transmission electron microscope (FEI). Profiles were identified and categorized using standardized morphological characteristics (Peters et al., 1991). Dendritic spines were small ( $\sim 0.1-0.2 \mu \mathrm{m}$ in diameter $)$, abutted terminals and sometimes emanated from dendritic shafts. MF terminals were identified by their large size $(\sim 1-1.5 \mu \mathrm{m}$ in diameter), irregular shapes, and presence of numerous small synaptic vesicles (Amaral and Dent, 1981).

Single ultrathin sections taken from the surface of sections from CA3b were examined from three rats from each sex. Silver-intensified immunogold (SIG) labeling for DOR appeared as black electron-dense particles. To avoid problems due to antibody penetration, random grid squares were selected at low-magnification if the grid square was within $10 \mu \mathrm{m}$ of the tissue plastic interface (i.e., the surface of the tissue; Milner et al., 2011) and contained morphologically identified MFs. Fifty MF profiles per rat were then collected in random fields of stratum lucidum from each block. All spine profiles that were in contact with a MF profile were counted and classified as DOR-labeled (containing at least 1 SIG particle) or non-DOR labeled. SIG particles in DOR-labeled spines were additionally classified as cytoplasmic, on the plasma membrane, or on the synapse.

\section{Statistics}

Data are presented as mean \pm SEM with $p<0.05$. Student's $t$ tests, $\chi^{2}$ test, analysis of covariance (ANCOVA), ANOVA, and repeatedmeasures ANOVA (RMANOVA) were conducted using Prism (Graphpad Software). A RMANOVA was used to evaluate group differences in fEPSP slope as stimuli were increased from minimal to maximal. We chose RMANOVA for this because this test enabled us to compare differences in a mean value (fEPSP slope) over several different points in succession (stimulus intensity) in different groups (male and female rats). A key point in using the RMANOVA for this comparison is that there was a common independent variable (stimulus intensity) that was sampled successively as it increased, and this was done for each group. In contrast, we chose an ANCOVA to evaluate how two dependent variables (fEPSP slope and fiber volley amplitude) change together (and therefore correlate), and how this change might vary between different experimental groups (for example, male and female rats).

Student's $t$ tests were two-tailed. For ANOVA and RMANOVA, post hoc analysis was conducted using Bonferroni's tests; interactions between factors are not reported because they were not significant. Where there was homoscedasticity of variance, determined by Bartlett's test, data were log transformed or Welch's correction for unequal variance was applied before statistical analysis.

\section{Results}

\section{MF basal transmission in males and females}

MF basal transmission was assessed in 38 slices from 32 male rats and 93 slices from 73 female rats (diestrus-1: 21 slices, 16 rats; diestrus-2: 20 slices, 11 rats; proestrus: 34 slices, 26 rats; estrus: 18 slices, 10 rats). As shown in Figure $1 A, B$, male fEPSPs were larger than females when all females were pooled. This effect was evident when slope was plotted as a function of stimulus intensity (two-way RMANOVA, $F_{(1,129)}=6.86, p=0.010$; Fig. $1 B 2$ ), or fiber volley amplitude (ANCOVA, $p=0.035$; data not shown). Notably, the differences were greater at the highest intensities of stimulation (Fig. 1B2, asterisks), suggesting that the sex difference was due to a greater maximum in males than females. Consistent with that idea, the mean fEPSP slope at half-maximal intensity did not exhibit a sex difference but the maximum intensity did (Table 1). 
A1
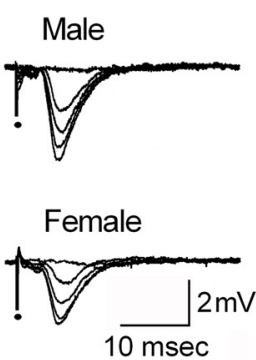

$\mathrm{C}_{1}$

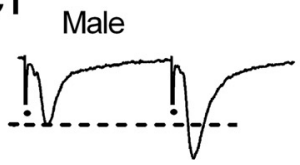

Female

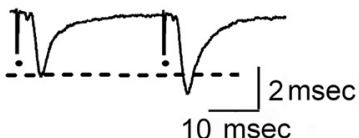

$10 \mathrm{msec}$
B1

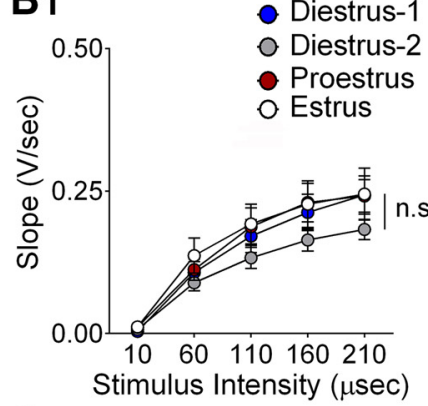

C2

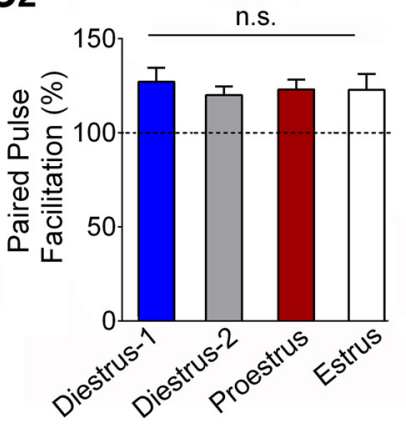

B2

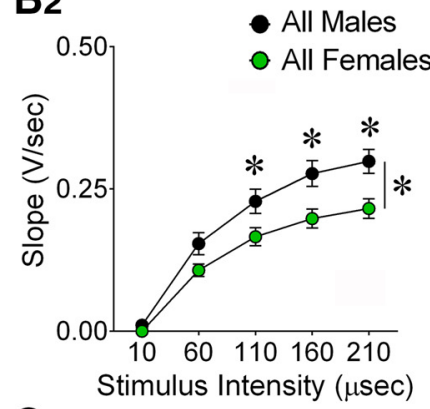

C3

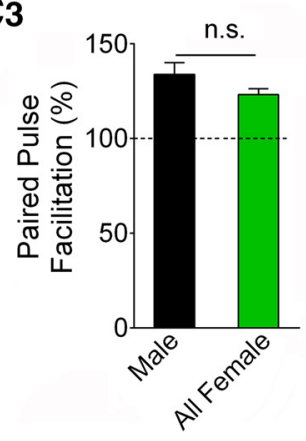

Figure 1. Basal MF transmission is greater in male rats compared with female rats. $A$, Representative responses to increasing stimulus strengths are superimposed for male and female rats. For this and all other figures, stimulus artifacts are marked by a dot and are truncated. B1, Mean fEPSP slopes from slices of female rats prepared on diestrus-1, diestrous-2, proestrous and estrous mornings are shown. Differences were not significant (two-way RMANOVA, $p>0.05$ ). B2, Mean fEPSP slopes for males, and all females (pooled), are plotted in relation to stimulus strength. Mean fEPSP slopes were greater in male rats compared with females (two-way RMANOVA, $p<0.05$ ). For statistical comparisons in this figure and all others, $F=$ degrees of freedom, $p$ values are provided in the text and asterisks over the symbols indicate statistical significance by post hoc test $(p<0.05)$. C1, Representative examples of PPF using half-maximal stimuli in a male and female rat. C2, There was no significant effect of estrous cycle stage on PPF of the fEPSP slope (two-way RMANOVA, $p>0.05$ ). C3, There was no significant sex difference in PPF of the fEPSP slope (two-way RMANOVA, $p>0.05)$.

Table 1. Specificity of sex differences in basal MF fEPSPs

\begin{tabular}{|c|c|c|c|c|c|c|c|c|c|c|c|c|}
\hline & \multicolumn{10}{|l|}{ fEPSP } & \multicolumn{2}{|l|}{ Volley } \\
\hline & \multicolumn{2}{|c|}{ Slope (V/s) } & \multicolumn{2}{|c|}{ Amplitude (mV) } & \multicolumn{2}{|c|}{ Area $(\mathrm{msec} \cdot \mathrm{mV})$} & \multicolumn{2}{|c|}{$\begin{array}{l}\text { Half-duration } \\
\text { (msec) }\end{array}$} & \multicolumn{2}{|c|}{$\begin{array}{l}\text { Latency to peak } \\
\text { (msec) }\end{array}$} & $\begin{array}{l}\begin{array}{l}\text { Amplitude } \\
(\mathrm{mV})\end{array} \\
100 \%\end{array}$ & $\begin{array}{l}\text { Latency to peak } \\
\text { (msec) }\end{array}$ \\
\hline \multicolumn{13}{|l|}{ Male } \\
\hline Mean & 0.16 & 0.30 & 0.30 & 0.50 & 2.38 & 1.94 & 9.73 & 9.01 & 6.59 & 5.98 & 0.12 & 3.02 \\
\hline SEM & 0.02 & 0.02 & 0.02 & 0.03 & 0.36 & 0.17 & 0.43 & 0.55 & 0.15 & 0.18 & 0.02 & 0.14 \\
\hline \multicolumn{13}{|l|}{ Female } \\
\hline Mean & 0.13 & 0.22 & 0.25 & 0.38 & 1.64 & 1.65 & 9.93 & 9.79 & 6.78 & 6.12 & 0.09 & 3.10 \\
\hline SEM & 0.01 & 0.01 & 0.01 & 0.02 & 0.13 & 0.06 & 0.28 & 0.53 & 0.09 & 0.13 & 0.01 & 0.09 \\
\hline$n$ (slices) & 92 & 93 & 92 & 93 & 92 & 40 & 92 & 40 & 92 & 40 & 69 & 69 \\
\hline$n$ (rats) & 63 & 63 & 63 & 63 & 63 & 35 & 63 & 35 & 63 & 35 & 52 & 52 \\
\hline$p$ & 0.075 & $0.011^{*}$ & $0.016^{*}$ & $0.002^{*}$ & $0.018^{*}$ & $0.047^{*}$ & 0.700 & 0.360 & 0.248 & 0.525 & 0.233 & 0.881 \\
\hline
\end{tabular}

Data are presented from males and pooled females. In contrast to fEPSP slope, amplitude and area, there were no significant differences in fEPSP half-duration, latency to peak, or fiber volleys. Measurements were either taken at $50 \%$ of the maximal stimulus intensity or maximal stimulus intensity. $p$ values are based on Student's $t$ test $\left({ }^{*} p<0.05\right)$.

Like fEPSP slope, the input-output curve for fEPSP amplitude versus stimulus intensity was greater in males than females (two-way RMANOVA, $F_{(1,129)}=12.46 ; p=0.001$; post hoc tests, $p>0.05$ for the four highest stimulus strengths; Table 1). However, there was no significant difference in half-duration (halfmaximal or maximal stimulation; Table 1).

When the four cycle stages of females were compared, there were no significant differences in fEPSP slopes, whether they were plotted as a function of stimulus intensity (two-way RMANOVA, $F_{(3,89)}=0.56, p=0.646$; Fig. $\left.1 B 2\right)$, or plotted as a function of fiber volley amplitude (ANCOVA; $p=0.120$; data not shown). There also were no significant differences in the input-output curves for fEPSP amplitudes (plotted in relation to stimulus intensity; two-way RMANOVA, $\left.F_{(3,89)}=0.66, p=0.576\right)$. Area and half-duration also showed no significant differences (using a half-maximal stimulus stimulus; one-way ANOVAs, area: $F_{(3,88)}$ $=1.48, p=0.226$; duration: $\left.F_{(3,89)}=1.98, p=0.122\right)$. However, fEPSP slopes of proestrous females were relatively high, and the input-output function (fEPSP slope vs stimulus intensity) was not significantly different from males (two-way RMANOVA, $\left.F_{(1,70)}=3.16, p=0.080\right)$.

Latency and fiber volleys were similar in all groups. There were no differences in latency to the peak of the fEPSP either when males were compared with all females (Table 1) or when 

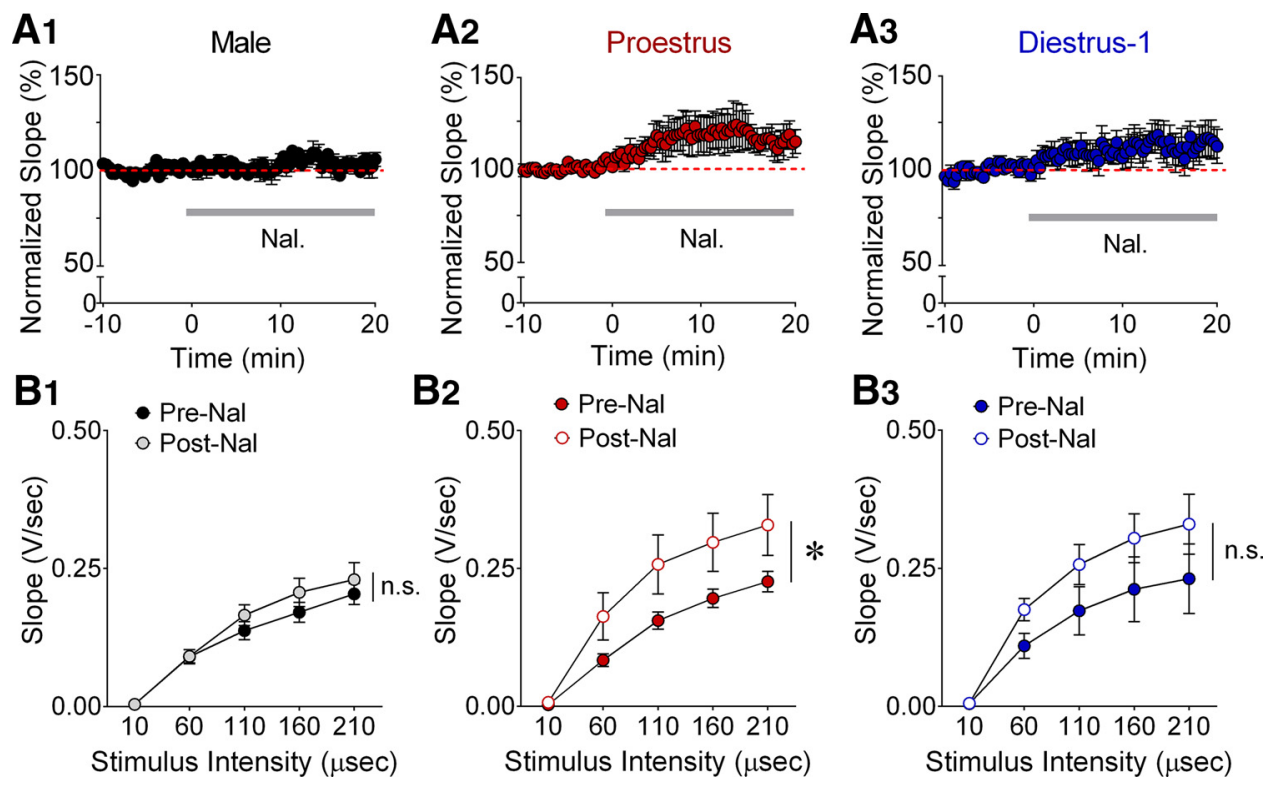

Figure 2. Naloxone increases MF transmission in female rats. $\boldsymbol{A}$, Using a half-maximal stimulus, the effects of naloxone (1 $\mu \mathrm{M})$ in males (A1), proestrous females (A2), and diestrous-1 females (A3) is shown. The red dotted line marks $100 \%$ or no change in the slope compared with the baseline period ( $0-10$ min before adding naloxone). $\boldsymbol{B}$, Input- output curves are plotted for the fEPSPs before and $20 \mathrm{~min}$ after addition of naloxone. The differences were statistically significant for proestrous females.

females at different cycle stages were compared (one-way ANOVA, $F_{(3,88)}=1.49, p=0.222$ ). There also were no differences in the latency to the peak of the fiber volley (males vs all females: Table 1; females at different cycle stages: one-way ANOVA, $\left.F_{(3,65)}=0.74, p=0.275\right)$. The amplitude of the maximal fiber volley was not significantly different between males and females (Table 1) or among females at different cycle stages (oneway ANOVA, $\left.F_{(3,65)}=0.58, p=0.630\right)$. It should be noted that a few slices in each group did not exhibit a detectable fiber volley, so they were not included. This is unlikely to have influenced the results, because there were no significant sex differences in the number of slices without fiber volleys ( $\chi^{2}$ test, male vs all females, $p=0.380)$ and no estrous cycle-dependent differences among females ( $\chi^{2}$ test, $\left.p=0.451\right)$.

Together, the results demonstrate that male rats had greater fEPSP slopes, amplitudes, and areas than female rats. These differences were specific because there were no sex differences in latency, duration, or fiber volleys. However, the differences were small and mostly at the maximum of the input-output function. It should also be noted that differences in subsets of these animals were not always clear (Fig. 2); they were only significant when data were pooled (Fig. 1).

\section{No significant sex differences in PPF}

Using a half-maximal stimulus and a $40 \mathrm{~ms}$ interstimulus interval, the interval that elicits the greatest MF PPF (Salin et al., 1996), there were no sex differences (Student's $t$ test, $p=0.161$; Fig. 1B2) and no cycle-dependent differences in PPF (one-way ANOVA, $F_{(3,88)}=0.44, p=0.404$; Fig. $\left.1 B 3\right)$. Using a constant interstimulus interval (40 ms) and all stimulus strengths, there were no sex differences (two-way RMANOVA, $F_{(1,129)}=4.94, p=0.443$ ) or differences among females at different cycle stages (two-way RMANOVA, $\left.F_{(3,89)}=1.28, p=0.285\right)$. Because PPF is primarily due to a presynaptic mechanism (Zucker and Regehr, 2002), the most parsimonious explanation is that sex differences in MF fEPSP slopes (Fig. 1 $A, B$ ) were dependent on postsynaptic mechanisms.
Opioid receptors influence female but not male MF fEPSPs

Effects of the nonselective opioid receptor antagonist naloxone (1 $\mu \mathrm{M}$ ) on basal transmission were assessed in male ( 5 slices from 5 males) and female rats ( 7 slices from 5 proestrous rats; 5 slices from 5 diestrous- 1 rats). Proestrous morning and diestrous- 1 morning were chosen because these cycle stages reflect times during the estrous cycle when serum levels of $17 \beta$-estradiol are at their peak (proestrous morning) and are low (diestrous-1 morning; Freeman, 1984). Effects of $17 \beta$-estradiol were of particular interest because it is a modulator that produces robust cycledependent changes in hippocampal synaptic transmission in the female rat (Woolley, 1998; Foy, 2001; Smith et al., 2009; Barha and Galea, 2010; Kramár et al., 2013; Bean et al., 2014; Sellers et al., 2014), and is implicated in the opioid receptor-dependent changes (Williams et al., 2011a,b). The morning of diestrus-1 was chosen instead of estrus because on estrous morning the recent decline in serum levels of progesterone exerts effects in addition to those caused by the surge in $17 \beta$-estradiol occurring during the previous day. Diestrus- 2 is not ideal because serum levels of $17 \beta$-estradiol slowly rise at that time as the preovulatory changes in ovarian $17 \beta$-estradiol secretion begin (Freeman, 1984). Note that in these experiments, vehicle $(0.9 \% \mathrm{NaCl})$ was not tested because in previous experiments using the same age, strain and species, it did not affect MF transmission or plasticity (Skucas et al., 2013).

Naloxone was bath-applied for $20 \mathrm{~min}$ to determine its effects on fEPSP slope (Fig. 2). There was no detectable effect in males using a half-maximal stimulus strength (Fig. $2 A, B$ ), but fEPSP slope increased in proestrous rats (Fig. $2 A, B$ ). When the inputoutput functions (stimulus intensity vs fEPSP slope) were compared before and after naloxone, there was no significant change in fEPSP slopes in male rats (two-way RMANOVA, $F_{(1,8)}=0.80$, $p=0.397$; Fig. $2 B 1$ ) but naloxone increased fEPSP slopes in proestrous females (two-way RMANOVA, $F_{(1,12)}=11.06, p=$ 0.006 ), particularly at high stimulus strengths (post hoc test, $p<$ 0.05 for the maximal intensity; Fig. 2B2). The input-output relationship for fEPSP slopes of males and proestrous females were 
Table 2. Effects of naloxone on basal MF fEPSPs in males and females

\begin{tabular}{|c|c|c|c|c|}
\hline & \multicolumn{2}{|l|}{ fEPSP } & \multicolumn{2}{|l|}{ Volley } \\
\hline & $\begin{array}{l}\text { Half-duration } \\
\text { (msec) }\end{array}$ & $\begin{array}{l}\text { Latency to peak } \\
\text { (msec) }\end{array}$ & $\begin{array}{l}\text { Amplitude } \\
(\mathrm{mV})\end{array}$ & $\begin{array}{l}\text { Latency to peak } \\
\text { (msec) }\end{array}$ \\
\hline \multicolumn{5}{|c|}{ Male prenaloxone } \\
\hline Mean & 9.64 & 6.59 & 0.04 & 2.8 \\
\hline SEM & 0.44 & 0.26 & 0.01 & 0.14 \\
\hline \multicolumn{5}{|c|}{ Male postnaloxone } \\
\hline Mean & 9.9 & 6.7 & 0.03 & 2.2 \\
\hline SEM & 0.39 & 0.2 & 0.01 & 0.16 \\
\hline$n$ & 5 & 5 & 4 & 4 \\
\hline$p$ & 0.173 & 0.606 & 0.334 & 0.125 \\
\hline \multicolumn{5}{|c|}{ Proestrus prenaloxone } \\
\hline Mean & 11.66 & 6.79 & 0.06 & 2.79 \\
\hline SEM & 0.49 & 0.2 & 0.01 & 0.07 \\
\hline \multicolumn{5}{|c|}{ Proestrus postnaloxone } \\
\hline Mean & 12.08 & 7.18 & 0.05 & 2.48 \\
\hline SEM & 1.61 & 0.23 & 0.01 & 0.10 \\
\hline$n$ & 7 & 7 & 6 & 6 \\
\hline$p$ & 0.544 & 0.114 & 0.156 & 0.31 \\
\hline \multicolumn{5}{|c|}{ Diestrus-1 prenaloxone } \\
\hline Mean & 11.06 & 7.10 & 0.06 & 2.74 \\
\hline SEM & 0.49 & 0.26 & 0.01 & 0.13 \\
\hline \multicolumn{5}{|c|}{ Diestrus-1 postnaloxone } \\
\hline Mean & 10.5 & 7.23 & 0.07 & 2.64 \\
\hline SEM & 0.4 & 0.29 & 0.05 & 0.15 \\
\hline$n$ & 5 & 5 & 5 & 5 \\
\hline$p$ & 0.125 & 0.621 & 0.675 & 0.367 \\
\hline
\end{tabular}

Males, proestrous females, and diestrous- 1 females were compared before and 20 min after the application of naloxone ( $n=$ rats; 1 slice/rat). Proestrous and diestrous- 1 rats had greater maximal fEPSP slopes after naloxone, but there were no significant changes in half-duration, latency to peak, volley amplitude, or latency to the peak of the volley. Measurements were either taken at $50 \%$ of the maximal stimulus intensity (latency) or maximal stimulus intensity (half-duration, fiber volley measurements). Input- output curves are compared in the text. $p$ values are based on paired $t$ test $\left({ }^{*} p<0.05\right)$

not significantly different after naloxone (two-way RMANOVA, $F_{(1,10)}=1.98, p=0.190$; Fig. 2B1,B2). Naloxone increased fEPSPs of diestrous- 1 rats but the effect was less robust than proestrous rats because there was no significant change in the input-output function (two-way RMANOVA, $F_{(1,8)}=2.08, p=$ 0.187; Fig. 2C1,C2).

Naloxone had no effect on the characteristics of fEPSPs that lacked sex differences (Table 2). Specifically, naloxone did not affect fEPSP half-duration, mean latency to peak of the fEPSP, the amplitude of the maximal fiber volley, and the latency to the peak of the maximal fiber volley (all $p$ values $>0.05$; Table 2). Naloxone also had no effect on PPF (Table 3), which supports the idea that the mechanism underlying sex differences was postsynaptic.

\section{MOR antagonism selectively increases basal transmission in females}

As a nonselective antagonist, naloxone blocks MORs, DORs and $\kappa$-opioid receptors. Because there are few $\kappa$ opioid receptors in CA3 of the rat (Mansour et al., 1988; Unterwald et al., 1991; Mansour et al., 1996; for review, see Drake et al., 2007) and dynorphin, a $\kappa$-receptor agonist, had no effect on MF fEPSPs in male Sprague-Dawley rats (Salin et al., 1995), MF transmission was examined using a MOR antagonist (CTOP, $300 \mathrm{nM}$ ) and DOR antagonist (NTI; $1 \mu \mathrm{M}$ ). Proestrous females were used instead of diestrous-1 females because proestrous females exhibited the most robust effects of naloxone.

The effects of CTOP and NTI on basal transmission were assessed in slices from a new cohort of males ( 6 slices of 6 different rats) and proestrous females ( 5 slices of 5 different rats). In slices from male rats, half-maximal fEPSP slopes were similar before
Table 3. Opioid receptor antagonists did not influence PPF

\begin{tabular}{lccc}
\hline PPF & NAL & CTOP & NTI \\
\hline Male predrug & & & \\
$\quad$ Mean & 127.4 & 128.9 & 139.3 \\
SEM & 5.5 & 8.6 & 8.7 \\
Male postdrug & & \\
$\quad$ Mean & 124.4 & 135.9 & 138.8 \\
SEM & 7.7 & 11.1 & 13.2 \\
$n$ & 5 & 6 & 5 \\
$p$ & 0.632 & 0.529 & 0.978 \\
Proestrus predrug & & & 131.6 \\
Mean & 121.0 & 147.2 & 10.6 \\
SEM & 5.0 & 10.8 & 115.3 \\
Proestrus postdrug & 126.3 & 136.1 & 6.7 \\
Mean & 6.7 & 13.8 & 5 \\
SEM & 7 & 5 & 0.097 \\
$n$ & 0.523 & 0.334 & \\
$p$ & & & \\
\hline PPF of fEPSP slopes are shown for experiments where naloxone (Nal), (TOP, or NTI were bath-applied $(n=$ rats; 1 \\
slice/rat). There were no detectable effects on PPF. $p$ values reflect the outcomes from paired $t$ test.
\end{tabular}

bath application of $300 \mathrm{~nm}$ CTOP and 20 min after its onset (94.6 $\pm 6.7 \%$ of baseline; Fig. $3 A 1)$ and there was no significant effect on the input-output function (two-way RMANOVA, $F_{(1,10)}=0.07, p=0.798$; Fig. 3A2). Higher concentrations $(1 \mu \mathrm{M})$ also had no effect (two-way RMANOVA, $F_{(1,4)}=0.55, p=0.499$; $n=3$ slices from 3 rats; data not shown). In contrast, $300 \mathrm{nM}$ CTOP increased fEPSPs in proestrous females (133.7 $\pm 5.5 \%$; Fig. $3 B 1$ ) and increased the input-output function (RMANOVA, $F_{(1,8)}=3.97, p=0.036$; Fig. 3B2). Interestingly, the greatest effect of $300 \mathrm{nM}$ CTOP in proestrous females was at the highest intensity of stimulation (Fig. 3B2, asterisks), which was the part of the input-output relation where sex differences, and effects of naloxone, were robust (Figs. 1B2,2B2). The data shown in Figure $3 B 1$ suggest that effects of CTOP were mediated by direct actions at receptors rather than indirect mechanisms such as protein synthesis because the latency to effect was similar to bicuculline, which directly acts at $\mathrm{GABA}_{\mathrm{A}}$ receptors (i.e., latency to peak effect, 15-20 min, using our flow system and recording chamber).

There was no significant effect of NTI on fEPSP slopes in male rats (two-way RMANOVA, $F_{(1,10)}=0.11, p=0.750$; Fig. 3C1,C2) or proestrous females (two-way RMANOVA, $F_{(1,8)}=0.05, p=$ 0.828; Fig. 3D1,D2). There was no effect of NTI on PPF (Table 3 ). These data suggest that DORs do not regulate MF basal transmission in males or females.

PPF was unaffected by CTOP in proestrous females (Table 3), again suggesting a postsynaptic site of action. One potential mechanism is coupling of MORs to postsynaptic $\mathrm{GABA}_{\mathrm{B}}$ receptors, which occurs in hypothalamus (Kelly et al., 1992; Lagrange et al., 1996). In support of that hypothesis, the $\mathrm{GABA}_{\mathrm{B}}$ receptor antagonist saclofen $(200 \mu \mathrm{M} ; 30 \mathrm{~min})$ prevented the effect of CTOP without altering PPF (Fig. 3E). Thus, PPF was $104.8 \pm$ $5.3 \%$ of the baseline after $30 \mathrm{~min}$ of exposure to saclofen (paired $t$ test, $p=0.452$ ). Saclofen did not have a consistent effect on the slope: $30 \mathrm{~min}$ after exposure to saclofen the fEPSP slope was $102.9 \pm 13.4 \%$ of baseline, which was not a significant difference (paired $t$ test, $p=0.885 ; n=3$ slices of 3 rats). There was no consistent effect of CTOP on fEPSP slope after saclofen pretreatment $(104.1 \pm 16.2 \%$ of baseline; paired $t$ test, $p=0.601$; Fig. $3 E)$. In contrast to $\mathrm{GABA}_{\mathrm{B}}$ receptors, $\mathrm{GABA}_{\mathrm{A}}$ receptors did not appear to be critical to effects of CTOP, because the increase in fEPSP slope produced by CTOP was not blocked by pretreatment with $10 \mu \mathrm{M}$ BMI (for $30 \mathrm{~min}$ ). Thus, after pretreatment with BMI for 

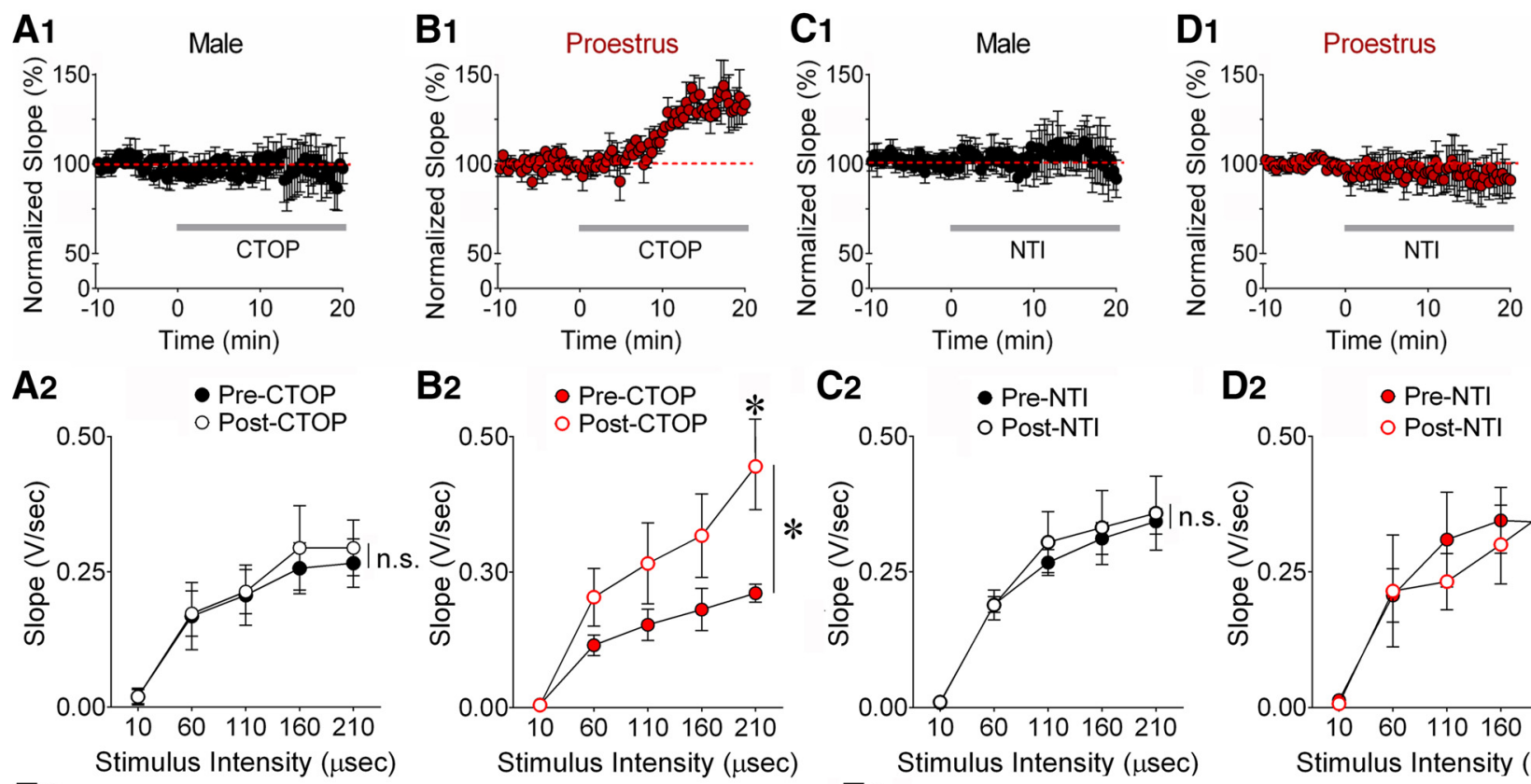

\section{E1}
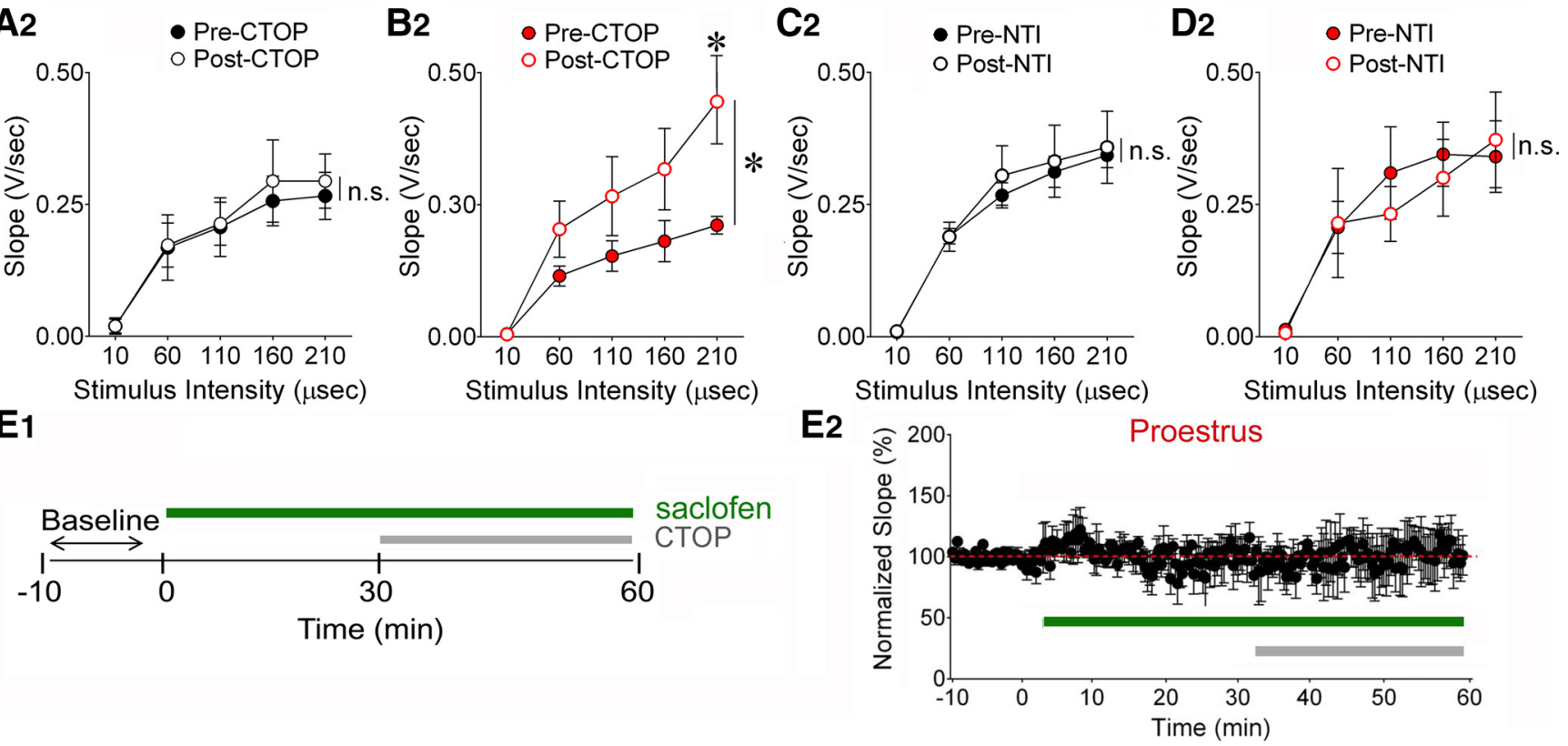

Figure 3. The MOR antagonist CTOP increases basal MF fEPSPs in proestrous female rats but the DOR antagonist NTI does not. $\boldsymbol{A}$, Normalized fEPSP slopes showing the 10 min baseline period and $20 \mathrm{~min}$ following addition of CTOP in male rats. A2, Mean fEPSP slopes plotted in relation to stimulus strength showed no change in fEPSP slopes in male rats following the application of CTOP (two-way RMANOVA, $p>0.05)$. B1, In proestrous female rats, fEPSP slopes elicited by half-maximal stimuli increased during exposure to (TOP. B2, CTOP significantly increased fEPSP slopes in the input-output function in proestrous female rats (two-way RMANOVA, $p<0.05$; post hoc test, $p<0.05$ ). C1, C2, NTI bath-application had little effect on fEPSP slopes elicited by half-maximal stimuli in male rats (C1) or the input- output function (C2; two-way RMANOVA, $p>0.05)$. D1, D2, In proestrous female rats, NTI had little effect on fEPSP slopes elicited by half-maximal stimuli $(\boldsymbol{D} 1)$ or the input- output function (D2; two-way RMANOVA, $p<0.05)$. $E$, Effects of CTOP on proestrous female fEPSPs were occluded by the GABA $A_{B}$ receptor antagonist saclofen. E1, A schematic of the experimental timeline is shown. E2, Saclofen $(200 \mu \mathrm{M})$ had little effect on fEPSP slope and subsequent exposure to CTOP (300 nM; $n=3 ; p>$ 0.05) failed to increase the fEPSP slope.

$30 \mathrm{~min}$, subsequent exposure to CTOP for $30 \mathrm{~min}$ led to an increase in the fEPSP $(123.5 \pm 7.1 \% ; n=3$ slices from 3 additional proestrous rats). When slices pretreated with BMI were compared with slices without pretreatment (Fig. 3B1), there was no statistical difference in the increase in the fEPSP slope induced by CTOP (Student's $t$ test, $p=0.427$ ).

\section{PTP}

Strong PTP in males and proestrous females

Synaptic plasticity was assessed in slices from males (13 slices from 8 rats) and females (10 slices from 7 diestrous- 1 rats; 16 slices from 9 diestrous- 2 rats; 14 slices from 8 proestrous rats; 14 slices from 8 estrous rats) that were a subset of those used to address basal transmission. In Figure $4 A$, schematics are used to show the protocol for a single stimulus train (Fig. 4A1) and the timeline for experiments using three trains to induce LTP (Fig. 4A2). The LF protocol, used to prevent SD in females (see Materials and Methods) still led to some SD (3/17 slices from proestrous females). These slices are excluded from the results described below.

Males and females both exhibited robust PTP (Fig. 4). Among females, there was a dependence on cycle stage (one-way ANOVA, Trains 1, 2, and 3, respectively, $F_{(3,50)}=5.39, p=0.003$;
$F_{(3,50)}=3.46, p=0.023 ; F_{(3,50)}=5.39, p=0.003$; Figure $\left.4 B 1\right)$ with proestrous rats exhibiting greater PTP than diestrous- 1 or diestrous-2 rats (post hoc tests, $p<0.05$; Fig. 4B2). PTP in proestrous and estrous rats were not significantly different for Trains 1 and 2 (post hoc tests, $p=0.507,0.459$, respectively) but were different for Train 3 ( $p<0.05$; Fig. 4B2). These data suggest relatively large PTP in proestrous/estrous rats compared with diestrus, with the most robust differences between proestrus and diestrus.

There were no differences in PTP between males and pooled females (Student's $t$ tests, PTP after Trains 1, 2, and 3, respectively: $p=0.918,0.986,0.345$; Fig. $4 C 1, C 2$ ). Interesting, fEPSP slopes in males had large responses (during Trains 1 and 3 ) compared with all females (two-way RMANOVA, Train 1: $F_{(1,65)}=$ 11.13, $p=0.001$; Train 2: $F_{(1,65)}=3.34, p=0.072$; Train 3: $F_{(1,65)}=$ $5.40, p=0.023$; Figure $4 C 1)$. The differences in responses during the trains without differences in PTP are surprising, and a potential explanation is the variability in females: relatively large changes in fEPSP slopes and PTP in proestrous females and small changes in diestrous- 1 and diestrous-2 females (Fig. 4B, C). Indeed, males and proestrous females showed no differences in PTP (Student's $t$ tests, 

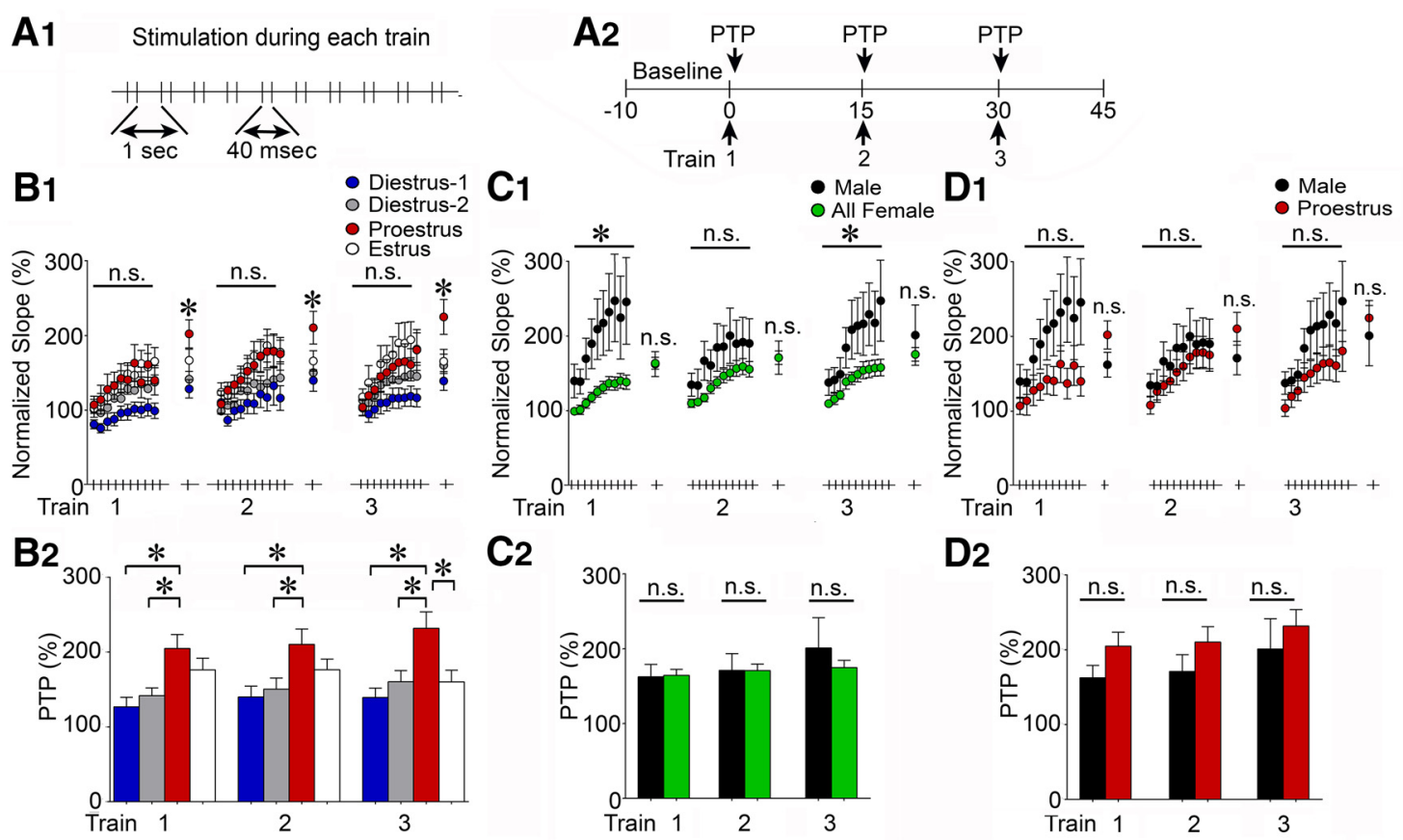

C2
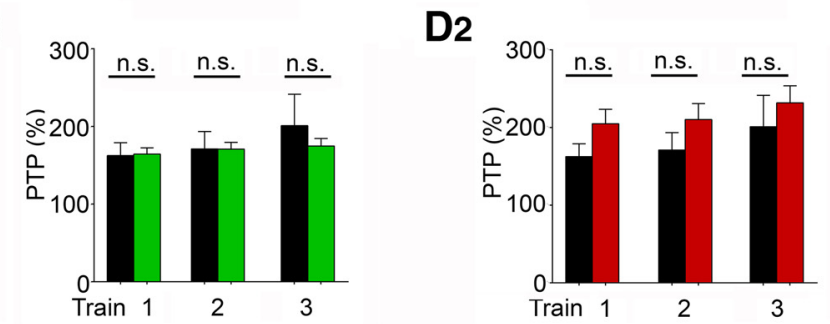

Figure 4. MFPTP in male and female rats. A1, A schematic illustrates the protocol for stimulation to induce PTP and LTP: paired half-maximal stimuli at $1 \mathrm{~Hz}$ for $10 \mathrm{~s}$. Three trains were triggered, 15 min apart. A2, A schematic illustrates the timeline of the experiment. After a baseline period to confirm fEPSPs were stable, stimulus trains were delivered. PTP was measured $60 \mathrm{~s}$ after the last stimulus of each train. B1, Mean fEPSP slopes during each train, and PTP after each train are shown for female rats at different estrous cycle stages. B2, The magnitude of PTP is compared across estrous cycle stages. Proestrous female rats had significantly greater PTP than diestrous- 1 and diestrous-2 female rats, and significantly greater PTP than estrous female rats following Train 3 (one-way ANOVA followed by post hoc tests, $p<0.05$ ). C1, C2, There was no significant sex difference in PTP between males and pooled females (Student's $t$ tests, $p>0.05$ ) but the fEPSP slopes of male rats increased more during Trains 1 and 3 compared with pooled females (two-way RMANOVA, $p<0.05$ ). D1, D2, PTP in male rats were not significantly different from proestrous females (two-way RMANOVA followed by post hoc tests, $p>0.05$ ). There were no differences in the fEPSP slopes during the trains either (two-way RMANOVAs, $p>0.05$ ).

PTP after Trains 1, 2, and 3, respectively: $p=0.102,0.205, p=0.501$; Fig. $4 D 1, D 2$ ) or changes in fEPSP slope during the trains (Train 1: $F_{(1,25)}=2.35, p=0.138$; Train 2: $F_{(1,25)}=0.48, p=0.495$; Train 3: $F_{(1,25)}=1.66, p=0.290$; Figure $\left.4 D 1\right)$.

In summary, males and proestrous rats had relatively large increases in fEPSP slopes during trains and in the magnitude of PTP after trains, compared with diestrous rats. The fEPSP slopes facilitated weakly during trains in diestrous females, and PTP was small.

Opioid receptor antagonists block PTP in both sexes

Effects of naloxone on synaptic plasticity were assessed in slices from males, proestrous females, and diestrous- 1 females ( 5 slices from 5 rats per group). The rats were the same as those used to examine effects of naloxone on basal transmission.

After adding naloxone for $15 \mathrm{~min}$, an input-output curve was used to determine whether the half-maximal stimulus strength had changed and if it had changed, it was adjusted so that a half-maximal stimulus would be used thereafter. Then slices were monitored for $5 \mathrm{~min}$ to confirm that the response to a half-maximal stimulus was stable in the continued presence of naloxone. An additional input-output function was conducted for confirmation. Next, the protocol for LTP induction was used. Naloxone was present for the rest of the experiment (Fig. 5A).

In male rats, naloxone significantly reduced PTP (Student's $t$ test, PTP after Trains 1, 2, and 3, respectively: $p=0.011,0.024$, 0.049; Fig. 5B1). Naloxone also blocked PTP in slices from proestrous female rats (Trains 1, 2, and 3, respectively: $p=0.0004$, $0.0007,0.023$; Fig. 5B2). In contrast, diestrous-1 rats showed small PTP and there was no significant effect of naloxone (Trains 1,2 , and 3, respectively: $p=0.180,0.133,0.098$; Fig. 5B3).
Effects of CTOP and NTI on PTP were assessed in the same rats that were used to study basal transmission. Experiments were like those with naloxone, but the input-output curve was examined $20 \mathrm{~min}$ instead of $15 \mathrm{~min}$ after CTOP to determine whether the half-maximal stimulus strength had changed. Responses were then monitored for an additional $30 \mathrm{~min}$, longer than the time used for experiments with naloxone, and input-output functions were examined every $10 \mathrm{~min}$, to ensure that responses were stable. The additional time was used to be certain that the response to CTOP had stabilized before testing PTP.

PTP was significantly reduced in slices of male rats treated with CTOP (Trains 1, 2, and 3, respectively: $p=0.019,0.005$, 0.023; Fig. $5 C 1$ ) and in proestrous rats (Trains 1,2 , and 4 , respectively: $p=0.035,0.001,0.049$; Fig. $5 C 2$ ). NTI significantly reduced PTP in male rats (Trains 1, 2, and 3, respectively3: $p=$ 0.003, 0.017, 0.030; Fig. 5D1) and proestrous female rats (Trains 1,2 , and 3, respectively: $p=0.004,0.0005,0.0002$; Fig. 5D2). Thus, CTOP and NTI had effects like naloxone.

\section{LTP}

LF-LTP occurs in female rats

LF-LTP occurred in proestrous females $(139.6 \pm 7.8 \%$, paired $t$ test, $p<0.001$; Fig. $6 A, B)$, estrous rats $(116.6 \pm 6.6 \%, p=0.002$; Fig. $6 B)$, and diestrous- 2 rats $(114.8 \pm 6.2 \%, p=0.041$; Fig. $6 B)$. LF-LTP was not induced in diestrous- 1 rats $(111.1 \pm 6.8 \%, p=$ 0.134 ; Fig. $6 B)$ or males $(109.0 \pm 7.3 \%, p=0.612$; Fig. $6 C)$. When all females were pooled, there was no significant difference from males (Fig. 6C). A direct comparison between males and proestrous females was significant (Student's $t$ test, $p=0.01$; Fig. $6 D$ ).

The lack of LF-LTP in male rats deserves comment because it was probably because of the protocol that was used to induce 


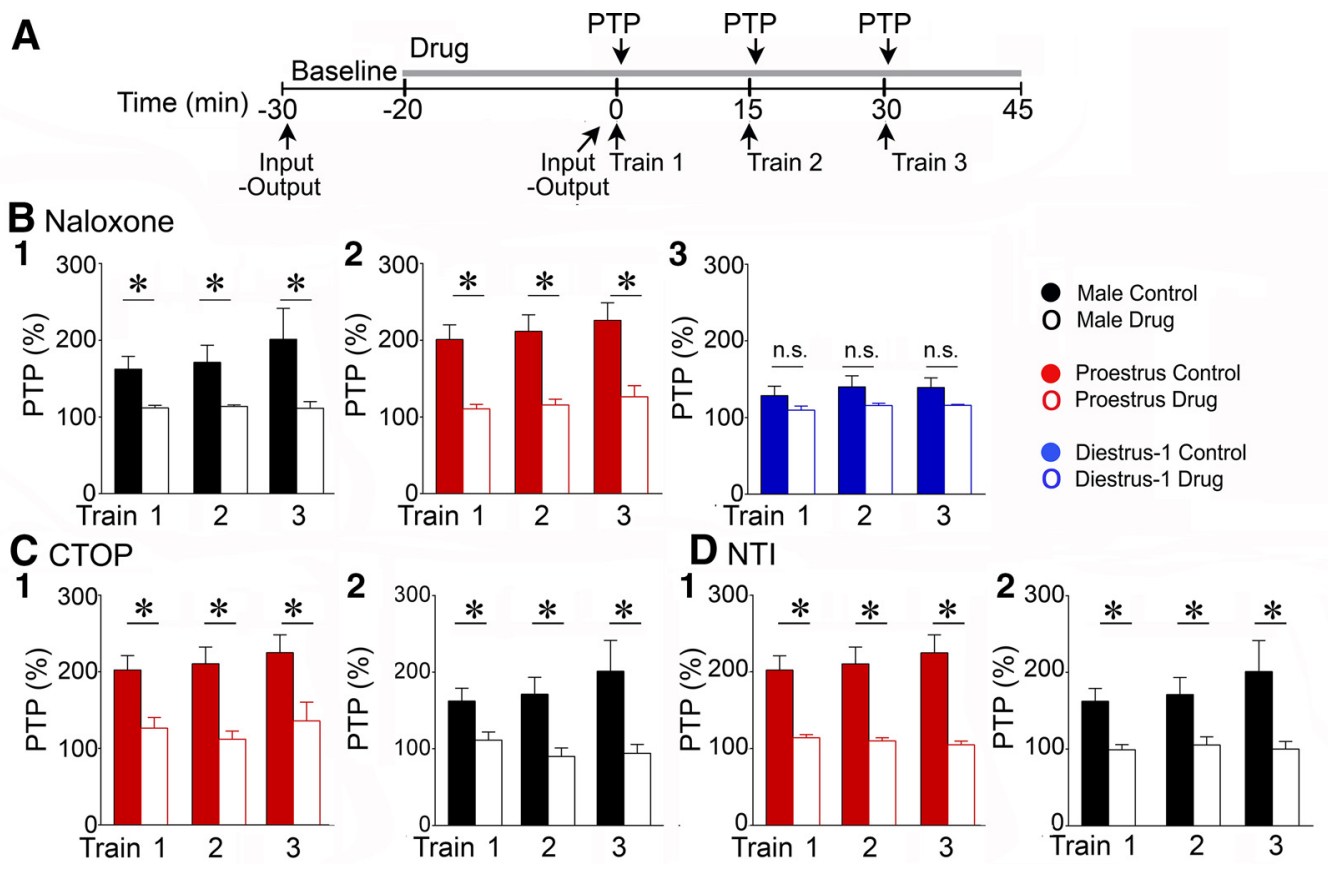

Figure 5. MOR and DOR antagonists block MF PTP regardless of sex. A, The experimental timeline is shown. After adding drug for $15-20$ min, the half-maximal stimulus strength was adjusted if the half-maximal stimulus changed. An additional baseline period $(\geq 5 \mathrm{~min})$ was used to confirm stability of the half-maximal response. Stimulus trains to induce LTP were triggered afterward. PTP was measured $60 \mathrm{~s}$ after each train. $\boldsymbol{B}$, Mean PTP is shown with and without naloxone in male rats (B1), proestrous female rats (B2) and diestrous-1 rats (B3). Naloxone significantly reduced PTP in male and proestrous female rats (Student's $t$ tests, $p<0.05$ ). PTP was small in diestrous-1 rats and was not significantly affected by naloxone (Student's $t$ test, $p>0.05$ ). C, Mean PTP is shown with and without CTOP in male rats (C1) and proestrous female rats (C2). CTOP significantly reduced PTP in both groups (Student's $t$ tests, $p<0.05)$. D, Mean PTP is shown with and without NTI in male rats (D1) and proestrous female rats (D2). NTI significantly reduced PTP in both groups (Student's $t$ tests, $p<0.05$ ).
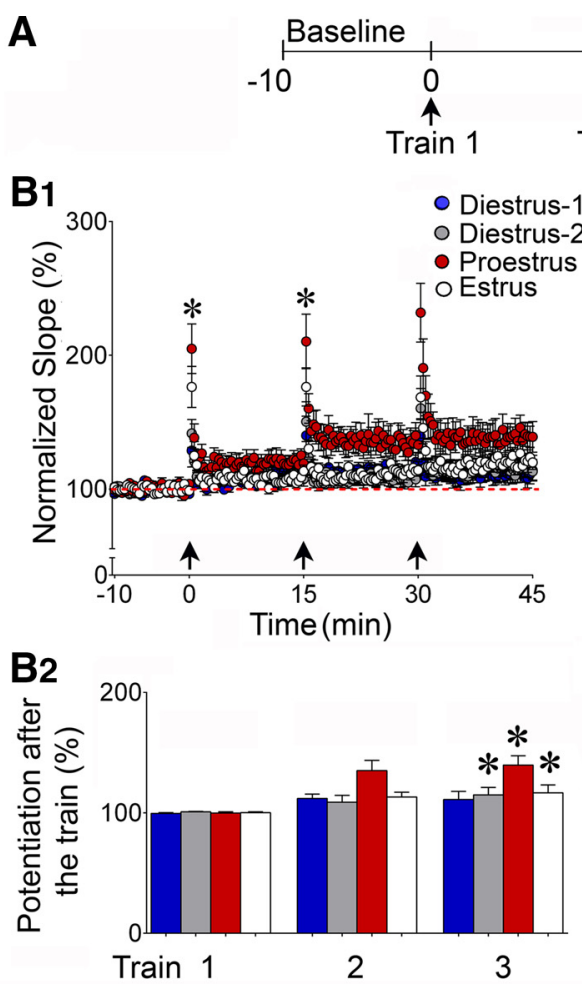

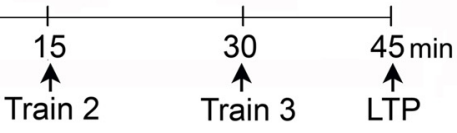

$\mathrm{C}_{1}$

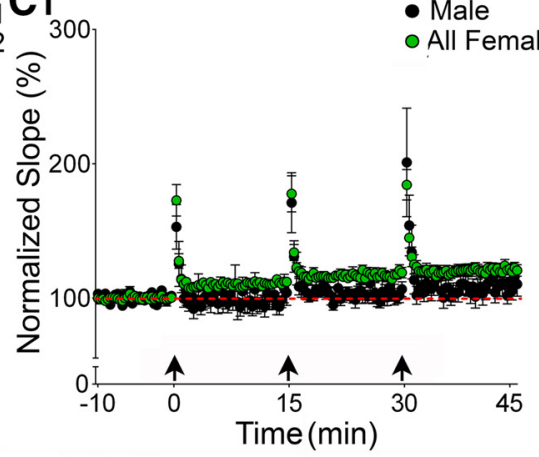

C2

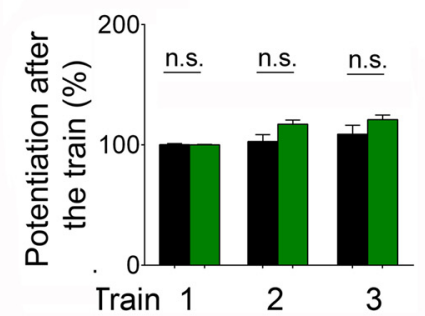

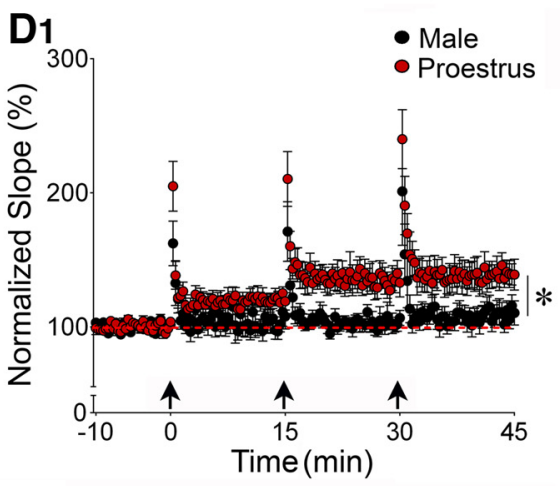

D2

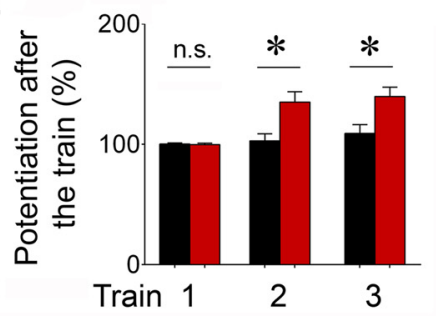

Figure 6. MF LF-LTP in proestrous female rats preferentially. $\boldsymbol{A}$, A schematic of the experimental procedure to study LTP is shown. $\boldsymbol{B} \mathbf{1}, \mathrm{LF}-\mathrm{LTP}$ in female rats at different cycle stages. $\boldsymbol{B} \mathbf{2}$, When measured $45 \mathrm{~min}$ following the third train. Potentiation was significant compared with the baseline for proestrous (134.0 $\pm 9.0 \%)$, estrous ( $120.7 \% \pm 5.7)$, and diestrous-2 rats ( $114.8 \pm 6.3 \%$; paired $t$ tests, $p<0.05)$, but not diestrous- 1 rats $(111.1 \pm 6.8 \%$; paired $t$ test, $p>0.05)$. C1, LF-LTP in all females (pooled) compared with males. $\mathbf{C 2}$, When measured 45 min after the third train all females (120.6 $\pm 3.7 \%)$ and males (109.2 $\pm 6.8 \%$ ) were not significantly different (Student's $t$ test, $p>0.05)$. D1, LF-LTP in proestrous female rats compared with males. D2, LF-LTP in proestrous females was significantly greater than male rats (Student's $t$ test, $p<0.05$ ). 

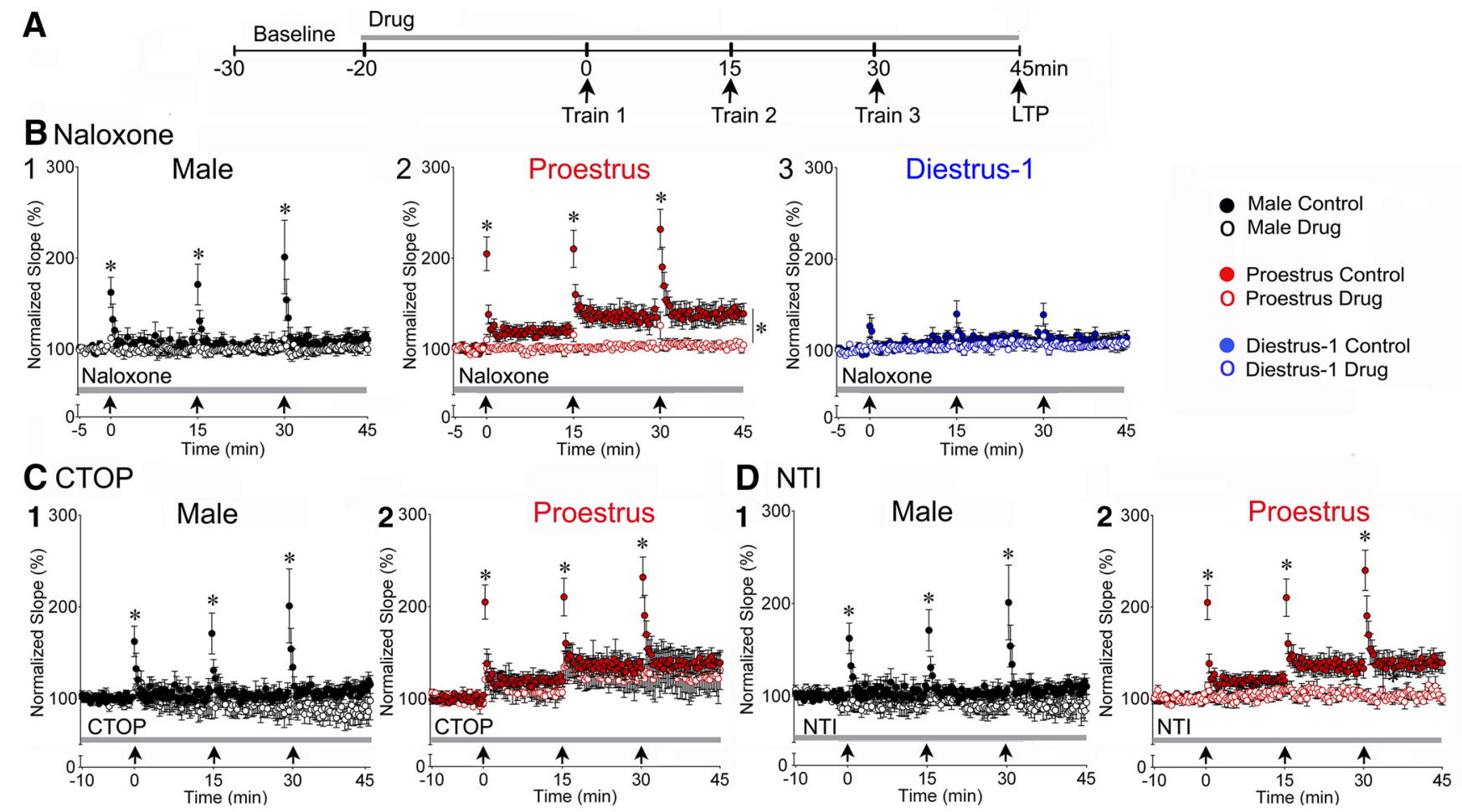

Figure 7. DOR antagonism blocks LF-LTP in proestrous females. $A$, The experimental timeline is shown. Three trains were triggered 15 min apart, and LF-LTP was measured 45 min after the initiation of the first train. B1, LF-LTP did not occur in male rats in untreated or naloxone-treated slices (paired $t$ tests, $p<0.05$ ). 2. Naloxone significantly reduced LF-LTP in proestrous females (Student's $t$ test, $p<0.05$ ). 3. LF-LTP did not occur in diestrous-1 females in untreated or naloxone-treated slices (paired $t$ tests, $p<0.05$ ). C1, The lack of LF-LTP in male rats is shown for untreated and CTOP-treated slices. C2, LF-LTP was not significantly different in untreated versus CTOP-treated slices of proestrous females (Student's $t$ tests, $p>$ 0.05). D1, The lack of LF-LTP in male rats is shown for untreated and NTI-treated slices. D2, LF-LTP in NTI-treated slices from proestrous rats was reduced compared with untreated slices (Student's $t$ tests, $p>0.05$ ).

LTP. Indeed, LTP occurs in males after longer trains $(>30 \mathrm{~s}$; Frausto et al., 2011) or higher stimulus frequencies ( $\geq 25 \mathrm{~Hz}$; Martin, 1983; Jin and Chavkin, 1999; Jamot et al., 2003). Thus, the threshold for LF-LTP may differ in males and proestrous females, but not the ability to elicit LTP.

DORs are responsible for LF-LTP in proestrous female rats We next examined the effects of naloxone on LF-LTP to determine whether opioid receptors modulate LF-LTP (Fig. 7A). LTP was reduced in naloxone-treated slices of proestrous rats compared with untreated slices $(104.3 \pm 0.8 \%$, Student's $t$ test, $p=$ 0.003 ; Fig. $7 B$ ). The results suggested that LF-LTP of proestrous female rats was mediated by opioid receptors.

CTOP and NTI were used to determine which opioid receptor contributed to antagonism of LF-LTP by naloxone in proestrous females. There was no significant effect of CTOP on LF-LTP in proestrous females (Student's $t$ test, $p=0.401$; Fig. $7 C$ ). However, NTI significantly reduced LF-LTP in proestrous females (Student's $t$ test, $p=0.024$; Fig. $7 D$ ) suggesting that DORs mediate LF-LTP in proestrous females. Across these experiments, the lack of LTP in males and diestrous- 1 females was consistent (Fig. $7 B-D)$.

\section{More DOR-labeled dendritic spines contact MFs in} proestrous females compared with males

The data described above suggested that DORs mediate LF-LTP in proestrous rats, presumably because DORs are highly expressed in proestrous rats. To address that hypothesis, immuno-EM was conducted in proestrous rats and males. Consistent with previous findings (Commons and Milner, 1997; Williams et al., 2011a),
SIG labeling for DORs was found in CA3 pyramidal cell bodies, dendritic shafts and dendritic spines in both females and males. However, significantly more dendritic spines in contact with MFs contained DOR SIG particles in proestrous females compared with males $(p<0.005$; Fig. $8 C, D)$. Specifically, females had $\sim 5$ times as many DOR labeled spines than males. Moreover, SIG particles in dendritic spines in proestrous females were found at the synapse ( $20 \%$ of 58$)$, on the plasma membrane (34\% of 58 ) and in the cytoplasm ( $45 \%$ of 58 ), whereas SIG particles in dendritic spines of males were only found on the plasma membrane ( $53 \%$ of 15$)$ or in the cytoplasm (47\% of 15$)$. Thus, more DORlabeled dendritic spines in contact with MFs in CA3 were found in proestrous females compared with males.

Interestingly, at other cycle stages in addition to proestrus, DOR labeling is primarily in distal dendrites or the cell layer rather than proximal dendrites (Williams et al., 2011a,b). In addition, DOR labeling in distal dendrites changes from the plasmalemma to the cytoplasm on proestrus (Williams et al., 2011a,b). Together, the data suggest that DOR trafficking occurs in the proestrous female, from the distal dendrites and cell bodies of pyramidal cells to the proximal dendritic spines that oppose MFs (Fig. 9).

\section{Discussion}

\section{Summary}

The results show that there are sex differences in MF transmission and LF-LTP. The most striking differences were in the MOR and DOR regulation of basal transmission and LF-LTP in proestrous females. Proestrous females were the only group 
A

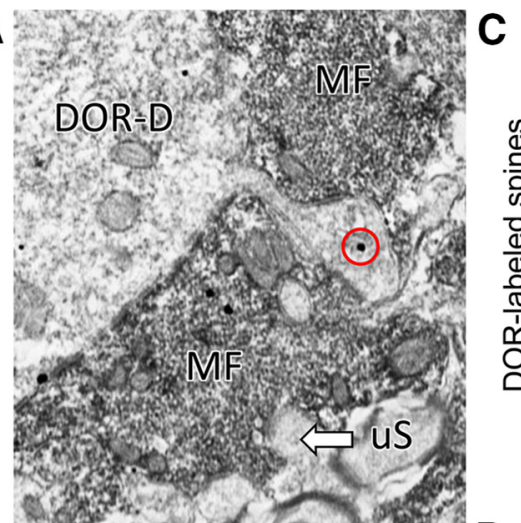

B

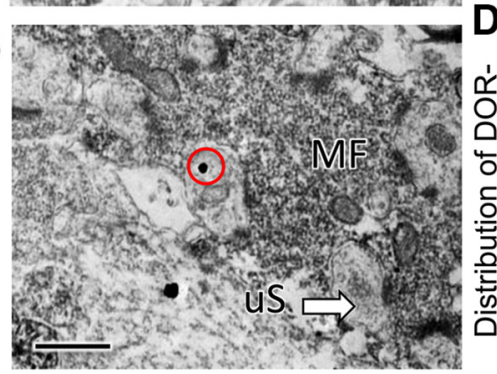

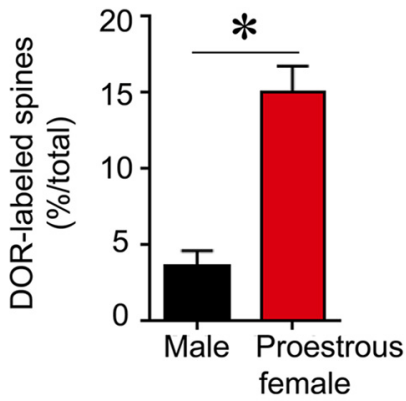

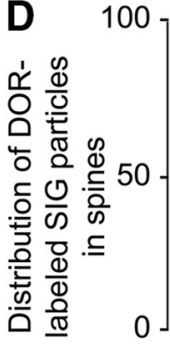

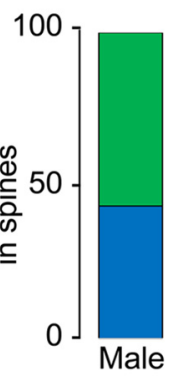

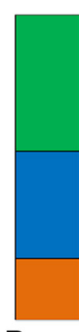

Proestrous female

Figure 8. Subcellular distribution of DOR SIG in dendritic spines. $A, B$, Representative electron micrographs from proestrous females show DOR SIG particles in the cytoplasm of dendritic spines (red circles) contacting MFs. The DOR-labeled spine in $\boldsymbol{A}$ emanates from the shaft of a DOR-labeled pyramidal cell dendrite (DOR-D). Unlabeled spines (US) are shown for comparison. Scale bar, $500 \mathrm{~nm}$. C, Graph showing significantly more DOR-labeled spines abutting MFs in CA3b in proestrous females compared with males $(n=3 / \mathrm{sex} ; 50 \mathrm{MFs} /$ rat were counted; Student's $t$ test, $p<0.005$ ). $\boldsymbol{D}$, The relative distribution of DOR SIG-labeled particles in dendritic spines abutting MFs is plotted for males and proestrous females. Proestrous females showed more DOR SIG particles at synapses (orange) but males did not. Both males and females showed cytoplasmic and membrane DOR SIG labeling (green, blue, respectively).

to exhibit robust LF-LTP, and postsynaptic DOR trafficking to MF synapses appears to contribute to this LTP. The data support the idea that there is a lower threshold for long-term synaptic plasticity in proestrous females, and suggest opioid receptors are potent regulators.

\section{Sex differences in basal transmission}

When all animals were pooled, males exhibited greater MF fEPSPs. However, subsets of animals did not necessarily exhibit the sex differences. These data are consistent with the small or variable sex differences in the number or density of MF synapses reported previously (Madeira et al., 1991; Parducz and GarciaSegura, 1993). Variability in our data are also consistent with the remarkable sensitivity of other sex differences, e.g., to the sex of the experimenter (Sorge et al., 2014), early life housing (Juraska et al., 1989), diet, and time of year (Kõks et al., 2000; Lund et al., 2001; Lephart et al., 2002; Luine et al., 2006; O’Bryant et al., 2011; Sumien et al., 2013).

Despite variability, pooled animals did show a sex difference in MF fEPSPs, primarily at the maximum of the input-output function. In addition, when effects of naloxone and CTOP were examined in proestrous females, the effects were mostly at the maximal intensities. The results are consistent with the idea that gonadal steroids modify the dynamic range of synapses (Rudick and Woolley, 2001; Scharfman and MacLusky, 2014).

\section{Relevance to past studies of hippocampus using proestrous rats}

The results suggest that MF plasticity is heightened on proestrous morning in adult female rats. This finding is consistent with in

vivo experiments showing that proestrous rats exhibited facilitated Schaffer collateral LTP in CA1 (Warren et al., 1995) which also was shown in slices (Good et al., 1999). Subsequent studies have demonstrated that $17 \beta$-estradiol enhances Schaffer collateral LTP when added to hippocampal slices (Foy et al., 1999; Smith and McMahon, 2006; Kramár et al., 2009; Kramár et al., 2013), leading to the conclusion that the rise in $17 \beta$-estradiol on proestrous morning is responsible for the increase in LTP at that cycle stage. Furthermore, adding $17 \beta$-estradiol to slices from naive rats, or systemically to ovariectomized rats before slice preparation, leads to a potentiated synaptic response in the absence of high-frequency stimulation (Teyler et al., 1980; Foy and Teyler, 1983; Wong and Moss, 1992; Landgren and Selstam, 1995; Fugger et al., 2001; Rudick and Woolley, 2001; Kramár et al., 2009, 2013). A difference from our experiments is that a requirement for opioid receptors has not been shown in CAl.

Notably, we previously found that CA3 excitability was high on proestrous and especially estrous mornings, reflected by the ability to evoke multiple population spikes (Scharfman et al., 2003). The present study is distinct by focusing on fEPSP slope and synaptic plasticity. Together the data suggest that synaptic plasticity is preferentially increased on proestrous morning, and estrous morning is a time of greater excitability.

\section{Opioid regulation of MF fEPSPs}

Naloxone and CTOP increased female MF fEPSPs. The lack of effects of drugs on PPF suggest a postsynaptic site of MOR action, consistent with MOR expression in CA3 pyramidal cell dendrites (Drake and Milner, 1999), and absence of sex differences in presynaptic expression of phosphorylated MORs (Gonzales et al., 2011).

The mechanism by which postsynaptic MORs inhibit fEPSPs could be similar to hypothalamus, where MORs are coupled to $\mathrm{GABA}_{\mathrm{B}}$ receptor-associated $\mathrm{K}^{+}$channels (Kelly et al., 1992; Lagrange et al., 1996). This mechanism is supported by occlusion of CTOP effects by a $\mathrm{GABA}_{\mathrm{B}}$ receptor antagonist, without changing PPF. However, an effect of postsynaptic MORs on basal transmission would require enkephalin release, and it is generally assumed that neuropeptide release requires high-frequency stimulation (Cheng and Pomeranz, 1979; Bartfai et al., 1988; Thureson-Klein and Klein, 1990). Notably, extremely high frequencies of stimulation may not be required to release enkephalins in proestrous females because MF enkephalin levels increase at that time (Torres-Reveron et al., 2008; Pierce et al., 2014). In addition, dense core vesicles containing neuropeptides move closer to the plasma membrane in response to $17 \beta$-estradiol (Tabatadze et al., 2013), making neuropeptide release more likely. Indeed, $17 \beta$ estradiol facilitated release of neuropeptide Y in CA1 (Ledoux et al., 2009). Furthermore, extrahippocampal enkephalin is released preferentially at $2 \mathrm{~Hz}$ rather than $>50 \mathrm{~Hz}$ (Wang et al., 1992; Han, 2003; Liang et al., 2010), as are some other neuropeptides (Whim 


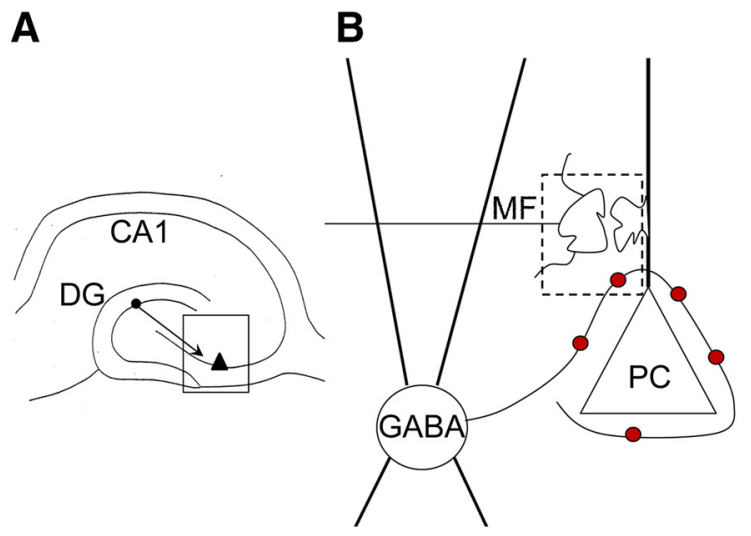

$C_{\text {Male }}$

1 Basal transmission
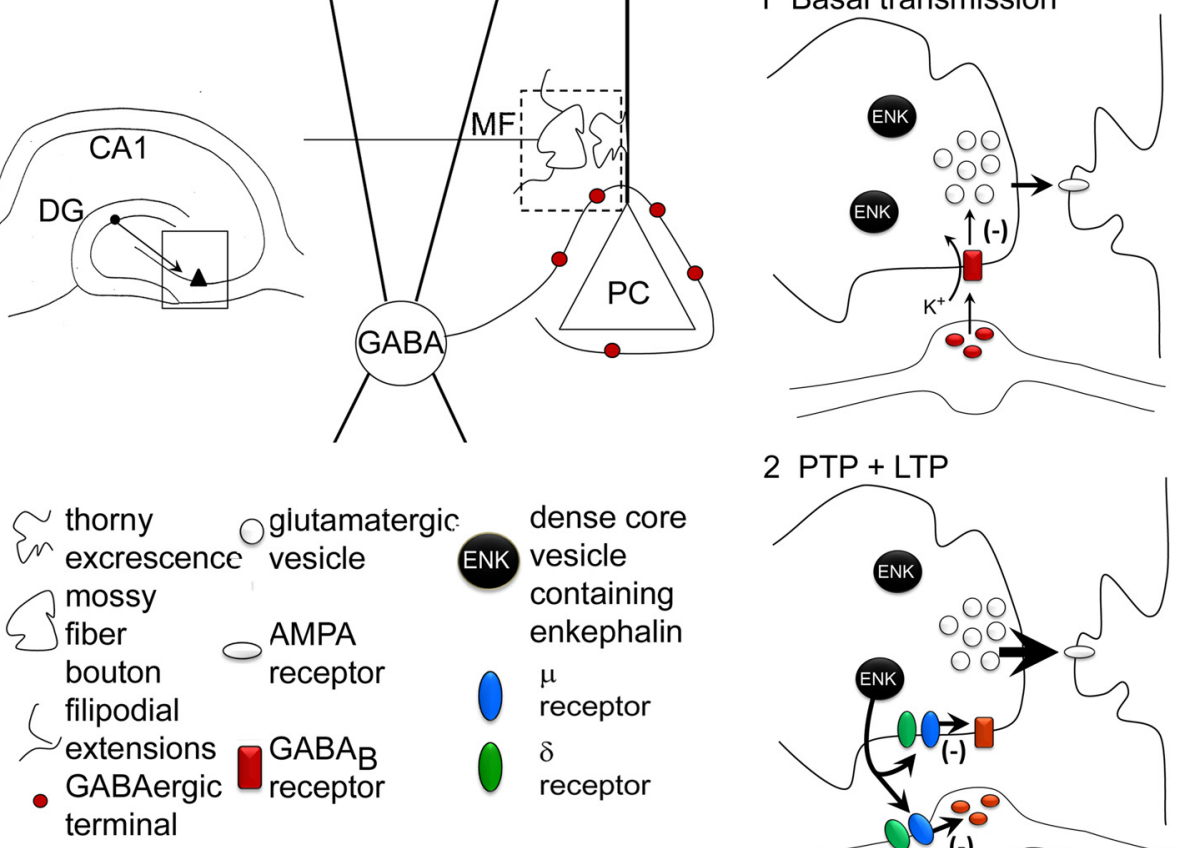

$2 \mathrm{PTP}+\mathrm{LTP}$

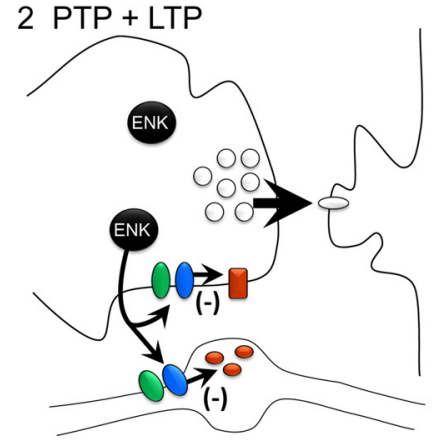

D Female proestrous morning

1 Basal transmission
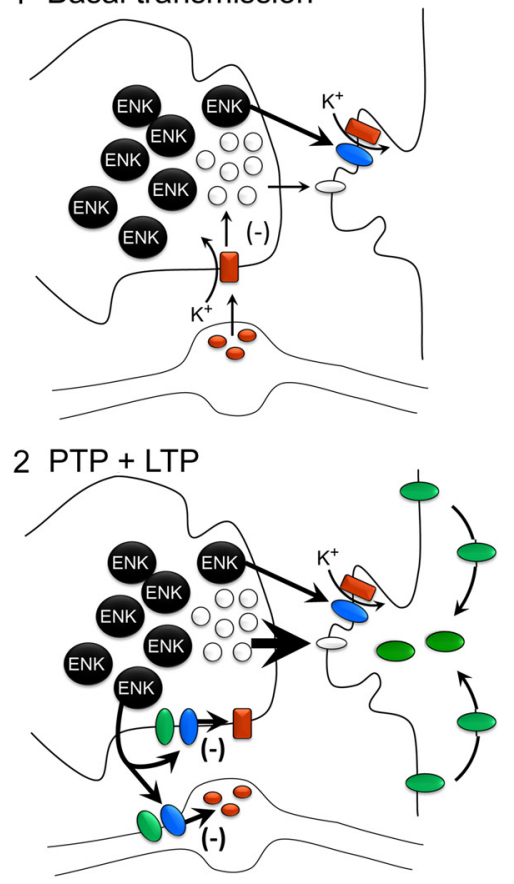

Figure 9. Opioid regulation of MF transmission and plasticity in male and female rats. $\boldsymbol{A}, \mathrm{A}$ schematic of the hippocampus showing the area $C A 3$ circuitry depicted in more detail in $\boldsymbol{B}$. DG, Dentate gyrus. $\boldsymbol{B}$, A schematic illustrates a MF innervating a CA3 pyramidal cell (PC). The area within the dotted lines is enlarged in $\boldsymbol{C}$ and $\boldsymbol{D}$. MFs innervate GABAergic interneurons but this is not shown in the diagram, for simplicity. Abbreviations are explained below the schematic. $C, A$ MF bouton and postsynaptic excrescence from the area surrounded by a dotted line in $B$ is shown for a male. $C 1$, Basal transmission in males. Inhibition of MF glutamate release by $G_{A B A}$ receptors has been shown in male rats (Hirata et al., 1992; Lambert and Wilson, 1993) so a GABA $A_{B}$ receptor is located on the MF bouton. Enkephalins are stored in dense core vesicles but enkephalin release is low at $\angle 0.1 \mathrm{~Hz}$, rates of stimulation that are used to study basal transmission ( $<0.1 \mathrm{~Hz}$; Cheng and Pomeranz, 1979 ; Bartfai et al., 1988; Thureson-Klein and Klein, 1990). (2, PTP. MOR- and DOR-mediated mechanisms of enkephalin modulation of PTP in males. MORs would block effects of MF GABA ${ }_{B}$ receptors, disinhibiting glutamate release (Jin and Chavkin, 1999). MOR activation would also reduce GABA release onto MF GABA ${ }_{B}$ receptors, disrupting the normal inhibition of MF glutamate release (Stumm et al., 2004). DORs are expressed on MFs and on interneurons (Commons and Milner, 1997), and had similar effects on male PTP as MORs, so DORs are included in the schematic adjacent to MORs. DORs presumably act in a similar manner as MORs because DORs inhibit GABAergic transmission (Zhang and Pan, 2010) and transmitter release (Kouchek et al., 2013) outside of hippocampus. D, The MF synapse is illustrated schematically for a female on proestrous morning. The levels of enkephalins are higher in proestrous female rats compared with male rats (Pierce et al., 2014). D1, Basal transmission in proestrous females. High enkephalin levels in MFs, and movement of dense core vesicles to the plasma membrane in response to 17 $\beta$-estradiol (Tabatadze et al., 2013) could lead to some release of enkephalin even under conditions of basal transmission (particularly at high stimulus strengths, where effects were most readily detected). Given that naloxone and (TOP increased basal transmission in proestrous females, and this was prevented by pretreatment with saclofen without a change in PPF, the schematic shows a postsynaptic site of action at MORs, which is associated with $G_{G A B}$ receptor. Regarding the type of interneuron that would normally activate $G A B A_{B}$ receptors of pyramidal cell dendrites in stratum lucidum, it is possible that some terminals of perisomatic-targeting cells (as shown in $\boldsymbol{B}$ ), ivy cells or neurogliaform cells (Freund and Buzsaki, 1996; Armstrong et al., 2012) do so. Stratum lucidum interneurons are strong candidates because their axon mainly innervates proximal dendrites, although mainly dendritic shafts rather than spines (Vida and Frotscher, 2000).D2, PTP + LTP in proestrous females. PTP was similar in males and females, so the same mechanisms for PTP in C2 are shown in D2. However, additional postsynaptic DORs are shown in D2 to explain the finding in proestrous females that DORs supported a type of LTP (LF-LTP) that was weak or absent in males. DORs are shown as moving (curved arrows) from CA3 pyramidal cells dendrites and cell bodies on proestrus toward MF synapses, consistent with the preferential location of DORs distally on pyramidal cell dendrites and in pyramidal cell bodies before proestrus (Williams et al., 2011a), and in postsynaptic spines on proestrus (Fig. 8).

and Lloyd, 1994; Whim and Moss, 2001). Thus, enkephalins are likely to regulate basal MF transmission in proestrous females by postsynaptic MORs but in males, enkephalins may not be released in sufficient concentrations or have the appropriate MORs to regulate basal transmission.

Diestrous-1 females showed a smaller effect of naloxone and CTOP on basal transmission. One would not expect any effect however, because MF enkephalin expression on diestrus- 1 is similar to males (Pierce et al., 2014). Moreover, serum levels of $17 \beta$ estradiol are low in diestrous-1 females (Freeman, 1984). One explanation is that hippocampal synthesis of $17 \beta$-estradiol, which is robust (Mukai et al., 2010; Fester et al., 2011) may be high on diestrus- 1 despite low serum levels of $17 \beta$-estradiol. As a result, there could be strong MOR inhibitory tone in all females, like hypothalamus, where opioid receptors in females tonically suppress circuitry required for the luteinizing hormone surge (Kelly et al., 1992).

\section{PTP and LTP}

PTP was blocked in males and females by CTOP and NTI. The reason that both drugs had effects is probably because more enkephalin was released than the concentration that is released during basal transmission. Thus, higher concentrations enkephalins can influence PTP by MORs and DORs in both sexes. Receptors are likely to be presynaptic because PTP is generally considered to depend on presynaptic mechanisms (Zucker and Regehr, 2002) and both MORs and DORs are found presynaptically (Commons and Milner, 1997; Fig. 9C2-D2).

Presynaptic receptors may exert effects as shown by Jin and Chavkin (1999) in males, where enkephalin normally activates presynaptic MF MORs that interact with $\mathrm{GABA}_{\mathrm{B}}$ receptors to inhibit MF glutamate release (Capogna et al., 1993). Enkephalin may also act on MORs and DORs on GABAergic neurons to suppress release of GABA and decrease MF $\mathrm{GABA}_{\mathrm{B}}$ activation (Stumm et al., 2004; Fig. 9). 
Different affinities of presynaptic and postsynaptic MORs for enkephalin could help explain the dominance of postsynaptic MORs during basal transmission and presynaptic MF MORs after higher frequency stimulation. Indeed, varied affinities of MORs have been reported and MFs preferentially express one subtype (MOR1D; Abbadie et al., 2000). Affinity may play an even greater role in proestrous females because MORs change affinity in response to estrogen (Piva et al., 1995).

The idea that postsynaptic DORs regulate LTP is consistent with the anatomical data showing that DORs on proestrous morning are trafficked away from the plasma membrane of the distal pyramidal cell dendrites (Williams et al., 2011a) and pyramidal cell layer (Williams et al., 2011b), and the results presented here that DORs are elevated in pyramidal cell dendritic spines on proestrus relative to males (Fig. 9D2). The influence of DORs on LTP could be related to their functions as G-protein coupled receptors (GPCRs; Roerig et al., 1992), leading to signal transduction critical to MF LTP. For example, DORs regulate cAMP (Law and Loh, 1993), which is critical to MF LTP (Huang et al., 1994). DORs also are associated with $\beta$ adrenergic receptors, which facilitate some forms of MF LTP (Hagena and Manahan-Vaughan, 2012; Ul Haq et al., 2012). A third possibility is suggested by the association of DORs with $\beta$ arrestin, which has actions related to trafficking of GPCRs and signal transduction (Cen et al., 2001; Shenoy and Lefkowitz, 2011). Therefore, $\beta$ arrestin could be involved in the trafficking of DORs and also could be involved in signaling pathways that support LF-LTP.

\section{Implications for sex differences in plasticity}

One would predict from the present study that there would be opioid receptor-regulated sex differences in CA3-dependent behavior. Although there are few studies, naloxone administration has been shown to decrease the preference of proestrous females for the novel arm of the Y maze (Farhadinasab et al., 2009). These data suggest that the animals treated with naloxone failed to distinguish what was spatially novel in their environment.

As discussed above, a lower threshold for synaptic plasticity on proestrus may be beneficial but also could be detrimental. Thus, female rats are more easily trained in opiate selfadministration than males (Roberts et al., 1989; Cicero et al., 2003; Roth and Carroll, 2004; Roth et al., 2004; Lynch, 2006). Our data suggest a contributing factor: MF LTP has a lower threshold in females than males when serum levels of $17 \beta$-estradiol are high. Our data would predict a role of DORs, and interestingly, infusion of the DOR antagonist naltriben into female hippocampus impairs conditioned place preference, a behavior that is linked to addiction and relapse (Billa et al., 2010). The data in rodents are interesting to consider in the context of addiction in women, because women often show a greater dependence on drugs of abuse than men (Cotto et al., 2010; Becker et al., 2012); perhaps DORs should be considered as a potential factor.

Regarding other maladaptive implications, opioid peptides in the MFs have been linked to hyperexcitability in males (Hong, 1992; Simmons and Chavkin, 1996; Bausch et al., 1998; Jeub et al., 1999). Interestingly, females develop epileptic seizures more rapidly in the kindling model of epilepsy, consistent with greater plasticity (Mishra et al., 1989). Our data suggest DORs could play a role. Other data (in males) also suggest DOR antagonism decreases seizure susceptibility in kindling (Schroeder et al., 1998). On the other hand, greater MOR-dependent inhibition of basal transmission in females could protect from seizures (Matejovská et al., 1998). These two seemingly opposing roles of of MORs and DORs may contribute to the reports that females may be pro- tected from seizures and seizure-related neuronal death, yet $17 \beta$ estradiol can facilitate seizures (Scharfman and MacLusky, 2006; Velísková, 2006; Velísková et al., 2010).

\section{Conclusions}

In conclusion, the results demonstrate that MF fEPSPs are reduced in females compared with males, and the sex difference is controlled by MORs. However, there is greater potential for longterm plasticity in females if they are at the proestrous stage of the estrous cycle, and this sex difference is due to DORs. $\mathrm{GABA}_{\mathrm{B}}$ receptors play a critical role. Because MFs are essential to hippocampal function, the results provide a basis to understand sexand hormone-related differences in hippocampal-dependent behavior. They also provide potential insight into disorders where the hippocampus plays a role, such as addiction and epilepsy.

\section{References}

Abbadie C, Pan YX, Pasternak GW (2000) Differential distribution in rat brain of $\mu$ opioid receptor carboxy terminal splice variants MOR-1C-like and MOR-1-like immunoreactivity: evidence for region-specific processing. J Comp Neurol 419:244-256. CrossRef Medline

Adámek S, Vyskočil F (2011) Potassium-selective microelectrode revealed difference in threshold potassium concentration for cortical spreading depression in female and male rat brain. Brain Res 1370:215-219. CrossRef Medline

Amaral DG, Dent JA (1981) Development of the mossy fibers of the dentate gyrus. I. A light and electron microscopic study of the mossy fibers and their expansions. J Comp Neurol 195:51-86. Medline

Amaral DG, Scharfman HE, Lavenex P (2007) The dentate gyrus: fundamental neuroanatomical organization (dentate gyrus for dummies). Prog Brain Res 163:3-22. CrossRef Medline

Armstrong C, Krook-Magnuson E, Soltesz I (2012) Neurogliaform and ivy cells: a major family of nNOS expressing GABAergic neurons. Front Neural Circuits 6:23. CrossRef Medline

Astur RS, Ortiz ML, Sutherland RJ (1998) A characterization of performance by men and women in a virtual Morris water task: a large and reliable sex difference. Behav Brain Res 93:185-190. CrossRef Medline

Barha CK, Galea LA (2010) Influence of different estrogens on neuroplasticity and cognition in the hippocampus. Biochim biophys Acta 1800: 1056-1067. CrossRef Medline

Bartfai T, Iverfeldt K, Fisone G, Serfözö P (1988) Regulation of the release of coexisting neurotransmitters. Annu Rev Pharmacol Toxicol 28:285-310. CrossRef Medline

Bausch SB, Chavkin C (1997) Changes in hippocampal circuitry after pilocarpine-induced seizures as revealed by opioid receptor distribution and activation. J Neurosci 17:477-492. Medline

Bausch SB, Esteb TM, Terman GW, Chavkin C (1998) Administered and endogenously released kappa opioids decrease pilocarpine-induced seizures and seizure-induced histopathology. J Pharmacol Exp Ther 284: 1147-1155. Medline

Bean LA, Ianov L, Foster TC (2014) Estrogen receptors, the hippocampus, and memory. Neuroscientist 20:534-545. CrossRef Medline

Becker JB, Perry AN, Westenbroek C (2012) Sex differences in the neural mechanisms mediating addiction: a new synthesis and hypothesis. Biol Sex Differ 3:14. CrossRef Medline

Billa SK, Xia Y, Morón JA (2010) Disruption of morphine-conditioned place preference by a $\delta 2$-opioid receptor antagonist: study of $\mu$-opioid and $\delta$-opioid receptor expression at the synapse. Eur J neurosci 32:625631. CrossRef Medline

Burstein SR, Williams TJ, Lane DA, Knudsen MG, Pickel VM, McEwen BS, Waters EM, Milner TA (2013) The influences of reproductive status and acute stress on the levels of phosphorylated $\delta$ opioid receptor immunoreactivity in rat hippocampus. Brain Res 1518:71-81. CrossRef Medline

Capogna M, Gähwiler BH, Thompson SM (1993) Mechanism of $\mu$-opioid receptor-mediated presynaptic inhibition in the rat hippocampus in vitro. J Physiol 470:539-558. Medline

Cen B, Yu Q, Guo J, Wu Y, Ling K, Cheng Z, Ma L, Pei G (2001) Direct binding of beta-arrestins to two distinct intracellular domains of the delta opioid receptor. J Neurochem 76:1887-1894. CrossRef Medline 
Cheng RS, Pomeranz B (1979) Electroacupuncture analgesia could be mediated by at least two pain-relieving mechanisms; endorphin and nonendorphin systems. Life sci 25:1957-1962. CrossRef Medline

Cicero TJ, Aylward SC, Meyer ER (2003) Gender differences in the intravenous self-administration of $\mu$ opiate agonists. Pharmacol Biochem Behav 74:541-549. CrossRef Medline

Commons KG, Milner TA (1997) Localization of $\delta$ opioid receptor immunoreactivity in interneurons and pyramidal cells in the rat hippocampus. J Comp Neurol 381:373-387. CrossRef Medline

Cotto JH, Davis E, Dowling GJ, Elcano JC, Staton AB, Weiss SR (2010) Gender effects on drug use, abuse, and dependence: a special analysis of results from the national survey on drug use and health. Gend Med 7:402413. CrossRef Medline

Derrick BE, Weinberger SB, Martinez JL Jr (1991) Opioid receptors are involved in an NMDA receptor-independent mechanism of LTP induction at hippocampal mossy fiber-CA3 synapses. Brain Res Bull 27:219-223. CrossRef Medline

Derrick BE, Rodriguez SB, Lieberman DN, Martinez JL Jr (1992) m opioid receptors are associated with the induction of hippocampal mossy fiber long-term potentiation. J Pharmacol Exp Ther 263:725-733. Medline

Drake CT, Milner TA (1999) $\mu$ Opioid receptors are in somatodendritic and axonal compartments of GABAergic neurons in rat hippocampal formation. Brain Res 849:203-215. CrossRef Medline

Drake CT, Chavkin C, Milner TA (2007) Opioid systems in the dentate gyrus. Prog Brain Res 163:245-263. CrossRef Medline

Eikermann-Haerter K, Dileköz E, Kudo C, Savitz SI, Waeber C, Baum MJ, Ferrari MD, van den Maagdenberg AM, Moskowitz MA, Ayata C (2009) Genetic and hormonal factors modulate spreading depression and transient hemiparesis in mouse models of familial hemiplegic migraine type 1. J Clin Invest 119:99-109. CrossRef Medline

Farhadinasab A, Shahidi S, Najafi A, Komaki A (2009) Role of naloxone as an exogenous opioid receptor antagonist in spatial learning and memory of female rats during the estrous cycle. Brain Res 1257:65-74. CrossRef Medline

Fester L, Prange-Kiel J, Jarry H, Rune GM (2011) Estrogen synthesis in the hippocampus. Cell Tissue Res 345:285-294. CrossRef Medline

Foy MR (2001) 17 $\beta$-estradiol: effect on CA1 hippocampal synaptic plasticity. Neurobiol Learn Mem 76:239-252. CrossRef Medline

Foy MR, Teyler TJ (1983) 17- $\alpha$-estradiol and 17- $\beta$-estradiol in hippocampus. Brain Res Bull 10:735-739. CrossRef Medline

Foy MR, Xu J, Xie X, Brinton RD, Thompson RF, Berger TW (1999) $17 \beta$ estradiol enhances NMDA receptor-mediated EPSPs and long-term potentiation. J Neurophysiol 81:925-929. Medline

Frausto SF, Ito K, Marszalec W, Swanson GT (2011) A novel form of lowfrequency hippocampal mossy fiber plasticity induced by bimodal mGlu1 receptor signaling. J Neurosci 31:16897-16906. CrossRef Medline

Freeman ME (1984) Neuroendocrine control of the ovarian cycle in the rat. In: Knobil and Neill's Physiology of Reproduction (Knobil J, Neil J, eds), pp 2327-2389. St Louis, MO: Elsevier Academic.

Freund TF, Buszáki G (1996) Interneurons of the hippocampus. Hippocampus 6:347-470. Medline

Fugger HN, Kumar A, Lubahn DB, Korach KS, Foster TC (2001) Examination of estradiol effects on the rapid estradiol mediated increase in hippocampal synaptic transmission in estrogen receptor $\alpha$ knock-out mice. Neurosci Lett 309:207-209. CrossRef Medline

Gonzales KL, Chapleau JD, Pierce JP, Kelter DT, Williams TJ, Torres-Reveron A, McEwen BS, Waters EM, Milner TA (2011) The influences of reproductive status and acute stress on the levels of phosphorylated m opioid receptor immunoreactivity in rat hippocampus. Front Endocrinol (Lausanne) 2:18. CrossRef Medline

Good M, Day M, Muir JL (1999) Cyclical changes in endogenous levels of oestrogen modulate the induction of LTD and LTP in the hippocampal CA1 region. Eur J Neurosci 11:4476-4480. CrossRef Medline

Hagena H, Manahan-Vaughan D (2012) Learning-facilitated long-term depression and long-term potentiation at mossy fiber-CA3 synapses requires activation of $\beta$-adrenergic receptors. Front Integr Neurosci 6:23. CrossRef Medline

Han JS (2003) Acupuncture: neuropeptide release produced by electrical stimulation of different frequencies. Trends Neurosci 26:17-22. CrossRef Medline

Harte-Hargrove LC, Maclusky NJ, Scharfman HE (2013) Brain-derived neurotrophic factor-estrogen interactions in the hippocampal mossy fi- ber pathway: implications for normal brain function and disease. Neuroscience 239:46-66. CrossRef Medline

Hirata K, Sawada S, Yamamoto C (1992) Quantal analysis of suppressing action of baclofen on mossy fiber synapses in guinea pig hippocampus. Brain Res 578:33-40. CrossRef Medline

Hong JS (1992) Hippocampal opioid peptides and seizures. Epilepsy Res Suppl 7:187-195. Medline

Huang YY, Li XC, Kandel ER (1994) cAMP contributes to mossy fiber LTP by initiating both a covalently mediated early phase and macromolecular synthesis-dependent late phase. Cell 79:69-79. CrossRef Medline

Jaffe DB, Gutiérrez R (2007) Mossy fiber synaptic transmission: communication from the dentate gyrus to area CA3. Prog Brain Res 163:109-132. CrossRef Medline

Jamot L, Matthes HW, Simonin F, Kieffer BL, Roder JC (2003) Differential involvement of the $\mathrm{m}$ and $k$ opioid receptors in spatial learning. Genes Brain Behav 2:80-92. CrossRef Medline

Jeub M, Lie A, Blümcke I, Elger CE, Beck H (1999) Loss of dynorphinmediated inhibition of voltage-dependent $\mathrm{Ca} 2+$ currents in hippocampal granule cells isolated from epilepsy patients is associated with mossy fiber sprouting. Neuroscience 94:465-471. CrossRef Medline

Jin W, Chavkin C (1999) m opioids enhance mossy fiber synaptic transmission indirectly by reducing $\mathrm{GABA}_{\mathrm{B}}$ receptor activation. Brain Res 821: 286-293. CrossRef Medline

Jonasson Z (2005) Meta-analysis of sex differences in rodent models of learning and memory: a review of behavioral and biological data. Neurosci Biobehav Rev 28:811-825. CrossRef Medline

Juraska JM, Fitch JM, Washburne DL (1989) The dendritic morphology of pyramidal neurons in the rat hippocampal CA3 area: II. Effects of gender and the environment. Brain Res 479:115-119. CrossRef Medline

Kelly MJ, Loose MD, Ronnekleiv OK (1992) Estrogen suppresses $\mu$-opioidand $\mathrm{GABA}_{\mathrm{B}}$-mediated hyperpolarization of hypothalamic arcuate neurons. J Neurosci 12:2745-2750. Medline

Kõks S, Männistö PT, Bourin M, Shlik J, Vasar V, Vasar E (2000) Cholecystokinin-induced anxiety in rats: relevance of pre-experimental stress and seasonal variations. J Psychiatry Neurosci 25:33-42. Medline

Kouchek M, Takasusuki T, Terashima T, Yaksh TL, Xu Q (2013) Effects of intrathecal SNC80, a delta receptor ligand, on nociceptive threshold and dorsal horn substance p release. J Pharmacol Exp Ther 347:258-264. CrossRef Medline

Kramár EA, Chen LY, Brandon NJ, Rex CS, Liu F, Gall CM, Lynch G (2009) Cytoskeletal changes underlie estrogen's acute effects on synaptic transmission and plasticity. J Neurosci 29:12982-12993. CrossRef Medline

Kramár EA, Babayan AH, Gall CM, Lynch G (2013) Estrogen promotes learning-related plasticity by modifying the synaptic cytoskeleton. Neuroscience 239:3-16. CrossRef Medline

Lagrange AH, Wagner EJ, Rønnekleiv OK, Kelly MJ (1996) Estrogen rapidly attenuates a $\mathrm{GABA}_{\mathrm{B}}$ response in hypothalamic neurons. Neuroendocrinology 64:114-123. CrossRef Medline

Lambert NA, Wilson WA (1993) Discrimination of post- and presynaptic $\mathrm{GABA}_{\mathrm{B}}$ receptor-mediated responses by tetrahydroaminoacridine in area CA3 of the rat hippocampus. J Neurophysiol 69:630-635. Medline

Landgren S, Selstam G (1995) Interaction between $17 \beta$-oestradiol and 3 $\alpha$-hydroxy-5 $\alpha$-pregnane-20-one in the control of neuronal excitability in slices from the CA1 hippocampus in vitro of guinea-pigs and rats. Acta Physiol Scand 154:165-176. CrossRef Medline

Law PY, Loh HH (1993) $\delta$-Opioid receptor activates cAMP phosphodiesterase activities in neuroblastoma $\times$ glioma NG108-15 hybrid cells. Mol Pharmacol 43:684-693. Medline

Ledoux VA, Smejkalova T, May RM, Cooke BM, Woolley CS (2009) Estradiol facilitates the release of neuropeptide $\mathrm{Y}$ to suppress hippocampusdependent seizures. J Neurosci 29:1457-1468. CrossRef Medline

Lephart ED, West TW, Weber KS, Rhees RW, Setchell KD, Adlercreutz H, Lund TD (2002) Neurobehavioral effects of dietary soy phytoestrogens. Neurotoxicol Teratol 24:5-16. CrossRef Medline

Liang J, Ping XJ, Li YJ, Ma YY, Wu LZ, Han JS, Cui CL (2010) Morphineinduced conditioned place preference in rats is inhibited by electroacupuncture at $2 \mathrm{~Hz}$ : role of enkephalin in the nucleus accumbens. Neuropharmacology 58:233-240. CrossRef Medline

Luine V, Attalla S, Mohan G, Costa A, Frankfurt M (2006) Dietary phytoestrogens enhance spatial memory and spine density in the hippocampus and prefrontal cortex of ovariectomized rats. Brain Res 1126:183-187. CrossRef Medline 
Lund TD, West TW, Tian LY, Bu LH, Simmons DL, Setchell KD, Adlercreutz H, Lephart ED (2001) Visual spatial memory is enhanced in female rats (but inhibited in males) by dietary soy phytoestrogens. BMC Neurosci 2:20. CrossRef Medline

Lynch WJ (2006) Sex differences in vulnerability to drug self-administration. Exp Clin Psychopharmacol 14:34-41. CrossRef Medline

Madeira MD, Sousa N, Paula-Barbosa MM (1991) Sexual dimorphism in the mossy fiber synapses of the rat hippocampus. Exp Brain Res 87:537545. Medline

Mansour A, Khachaturian H, Lewis ME, Akil H, Watson SJ (1988) Anatomy of CNS opioid receptors. Trends Neurosci 11:308-314. CrossRef Medline

Mansour A, Burke S, Pavlic RJ, Akil H, Watson SJ (1996) Immunohistochemical localization of the cloned $\mathrm{k}_{1}$ receptor in the rat CNS and pituitary. Neuroscience 71:671-690. CrossRef Medline

Maren S, De Oca B, Fanselow MS (1994) Sex differences in hippocampal long-term potentiation (LTP) and Pavlovian fear conditioning in rats: positive correlation between LTP and contextual learning. Brain Res 661: 25-34. CrossRef Medline

Martin MR (1983) Naloxone and long term potentiation of hippocampal CA3 field potentials in vitro. Neuropeptides 4:45-50. CrossRef Medline

Matejovská I, Velísková J, Velísek L (1998) Bicuculline-induced rhythmic EEG episodes: gender differences and the effects of ethosuximide and baclofen treatment. Epilepsia 39:1243-1252. CrossRef Medline

McEwen BS, Milner TA (2007) Hippocampal formation: shedding light on the influence of sex and stress on the brain. Brain Res Rev 55:343-355. CrossRef Medline

McQuiston AR (2007) Effects of m-opioid receptor modulation on $\mathrm{GABA}_{\mathrm{B}}$ receptor synaptic function in hippocampal CA1. J Neurophysiol 97:23012311. CrossRef Medline

Milner TA, Drake CT (2001) Ultrastructural evidence for presynaptic mu opioid receptor modulation of synaptic plasticity in NMDA-receptorcontaining dendrites in the dentate gyrus. Brain Res Bull 54:131-140. CrossRef Medline

Milner TA, Waters EM, Robinson DC, Pierce JP (2011) Degenerating processes identified by electron microscopic immunocytochemical methods. Methods Mol Biol 793:23-59. CrossRef Medline

Milner TA, Burstein SR, Marrone GF, Khalid S, Gonzalez AD, Williams TJ, Schierberl KC, Torres-Reveron A, Gonzales KL, McEwen BS, Waters EM (2013) Stress differentially alters $m$ opioid receptor density and trafficking in parvalbumin-containing interneurons in the female and male rat hippocampus. Synapse 67:757-772. CrossRef Medline

Mishra PK, Dailey JW, Reigel CE, Jobe PC (1989) Audiogenic convulsions in moderate seizure genetically epilepsy-prone rats (GEPR-3s). Epilepsy Res 3:191-198. CrossRef Medline

Mukai H, Kimoto T, Hojo Y, Kawato S, Murakami G, Higo S, Hatanaka Y, Ogiue-Ikeda M (2010) Modulation of synaptic plasticity by brain estrogen in the hippocampus. Biochim Biophys Acta 1800:1030-1044. CrossRef Medline

O’Bryant AJ, Allred RP, Maldonado MA, Cormack LK, Jones TA (2011) Breeder and batch-dependent variability in the acquisition and performance of a motor skill in adult Long-Evans rats. Behav Brain Res 224: 112-120. CrossRef Medline

Parducz A, Garcia-Segura LM (1993) Sexual differences in the synaptic connectivity in the rat dentate gyrus. Neurosci Lett 161:53-56. CrossRef Medline

Persson AI, Thorlin T, Eriksson PS (2005) Comparison of immunoblotted delta opioid receptor proteins expressed in the adult rat brain and their regulation by growth hormone. Neurosci Res 52:1-9. CrossRef Medline

Persson PA, Thorlin T, Rönnbäck L, Hansson E, Eriksson PS (2000) Differential expression of delta opioid receptors and mRNA in proliferating astrocytes during the cell cycle. J Neurosci Res 61:371-375. Medline

Peters A, Palay SL, Webster H deF (1991) The fine structure of the nervous system: neurons and their supporting cells. Oxford: Oxford UP.

Pierce JP, Kurucz OS, Milner TA (1999) Morphometry of a peptidergic transmitter system: dynorphin B-like immunoreactivity in the rat hippocampal mossy fiber pathway before and after seizures. Hippocampus 9:255-276. CrossRef Medline

Pierce JP, Kelter DT, McEwen BS, Waters EM, Milner TA (2014) Hippocampal mossy fiber leu-enkephalin immunoreactivity in female rats is significantly altered following both acute and chronic stress. J Chem Neuroanat 55:9-17. CrossRef Medline

Piva F, Limonta P, Dondi D, Pimpinelli F, Martini L, Maggi R (1995) Effects of steroids on the brain opioid system. J Steroid Biochem Mol Biol 53: 343-348. CrossRef Medline

Roberts DC, Bennett SA, Vickers GJ (1989) The estrous cycle affects cocaine self-administration on a progressive ratio schedule in rats. Psychopharmacology 98:408-411. CrossRef Medline

Roerig SC, Loh HH, Law PY (1992) Identification of three separate guanine nucleotide-binding proteins that interact with the delta-opioid receptor in NG108-15 neuroblastoma $\times$ glioma hybrid cells. Mol Pharmacol 41: 822-831. Medline

Rogawski MA (2012) Migraine and epilepsy: shared mechanisms within the family of episodic disorders. In: Jasper's basic mechanisms of the epilepsies (Noebels JL, Avoli M, Rogawski MA, Olsen RW, Delgado-Escueta AV, eds). Bethesda, MD: National Center for Biotechnology Information.

Roth ME, Carroll ME (2004) Sex differences in the escalation of intravenous cocaine intake following long- or short-access to cocaine selfadministration. Pharmacol Biochem Behav 78:199-207. CrossRef Medline

Roth ME, Cosgrove KP, Carroll ME (2004) Sex differences in the vulnerability to drug abuse: a review of preclinical studies. Neurosci Biobehav Rev 28:533-546. CrossRef Medline

Rudick CN, Woolley CS (2001) Estrogen regulates functional inhibition of hippocampal CA1 pyramidal cells in the adult female rat. J Neurosci 21:6532-6543. Medline

Salin PA, Weisskopf MG, Nicoll RA (1995) A comparison of the role of dynorphin in the hippocampal mossy fiber pathway in guinea pig and rat. J Neurosci 15:6939-6945. Medline

Salin PA, Scanziani M, Malenka RC, Nicoll RA (1996) Distinct short-term plasticity at two excitatory synapses in the hippocampus. Proc Natl Acad Sci U S A 93:13304-13309. CrossRef Medline

Scharfman HE (1997) Hyperexcitability in combined entorhinal/hippocampal slices of adult rat after exposure to brain-derived neurotrophic factor. J Neurophysiol 78:1082-1095. Medline

Scharfman HE, MacLusky NJ (2014) Differential regulation of BDNF, synaptic plasticity and sprouting in the hippocampal mossy fiber pathway of male and female rats. Neuropharmacology 76:696-708. CrossRef Medline

Scharfman HE, Smith KL, Goodman JH, Sollas AL (2001) Survival of dentate hilar mossy cells after pilocarpine-induced seizures and their synchronized burst discharges with area CA3 pyramidal cells. Neuroscience 104:741-759. CrossRef Medline

Scharfman HE, Mercurio TC, Goodman JH, Wilson MA, MacLusky NJ (2003) Hippocampal excitability increases during the estrous cycle in the rat: a potential role for brain-derived neurotrophic factor. J Neurosci 23:11641-11652. Medline

Scharfman HE, Hintz TM, Gomez J, Stormes KA, Barouk S, MalthankarPhatak GH, McCloskey DP, Luine VN, Maclusky NJ (2007) Changes in hippocampal function of ovariectomized rats after sequential low doses of estradiol to simulate the preovulatory estrogen surge. Eur J Neurosci 26:2595-2612. CrossRef Medline

Schroeder H, Becker A, Grecksch G, Schroeder U, Hoellt V (1998) The effect of pentylenetetrazol kindling on synaptic mechanisms of interacting glutamatergic and opioid system in the hippocampus. Brain Res 811:40-46. CrossRef Medline

Sellers K, Raval P, Srivastava DP (2014) Molecular signature of rapid estrogen regulation of synaptic connectivity and cognition. Front Neuroendocrinol. Advance online publication. CrossRef Medline

Shenoy SK, Lefkowitz RJ (2011) Beta-arrestin-mediated receptor trafficking and signal transduction. Trends Pharmacol Sci 32:521-533. CrossRef Medline

Simmons ML, Chavkin C (1996) Endogenous opioid regulation of hippocampal function. Int Rev Neurobiol 39:145-196. CrossRef Medline

Sindreu C, Palmiter RD, Storm DR (2011) Zinc transporter ZnT-3 regulates presynaptic Erk1/2 signaling and hippocampus-dependent memory. Proc Natl Acad Sci U S A 108:3366-3370. CrossRef Medline

Skucas VA, Mathews IB, Yang J, Cheng Q, Treister A, Duffy AM, Verkman AS, Hempstead BL, Wood MA, Binder DK, Scharfman HE (2011) Impairment of select forms of spatial memory and neurotrophin-dependent synaptic plasticity by deletion of glial aquaporin-4. J Neurosci 31:63926397. CrossRef Medline

Skucas VA, Duffy AM, Harte-Hargrove LC, Magagna-Poveda A, Radman T, Chakraborty G, Schroeder CE, MacLusky NJ, Scharfman HE (2013) Testosterone depletion in adult male rats increases mossy fiber transmis- 
sion, LTP, and sprouting in area CA3 of hippocampus. J Neurosci 33: 2338-2355. CrossRef Medline

Smith CC, McMahon LL (2006) Estradiol-induced increase in the magnitude of long-term potentiation is prevented by blocking NR2Bcontaining receptors. J Neurosci 26:8517-8522. CrossRef Medline

Smith CC, Vedder LC, McMahon LL (2009) Estradiol and the relationship between dendritic spines, NR2B containing NMDA receptors, and the magnitude of long-term potentiation at hippocampal CA3-CA1 synapses. Psychoneuroendocrinology 34:S130-S142. CrossRef Medline

Sorge RE, Martin LJ, Isbester KA, Sotocinal SG, Rosen S, Tuttle AH, Wieskopf JS, Acland EL, Dokova A, Kadoura B, Leger P, Mapplebeck JC, McPhail M, Delaney A, Wigerblad G, Schumann AP, Quinn T, Frasnelli J, Svensson CI, Sternberg WF, Mogil JS (2014) Olfactory exposure to males, including men, causes stress and related analgesia in rodents. Nat Methods 11:629-632. CrossRef Medline

Stumm RK, Zhou C, Schulz S, Höllt V (2004) Neuronal types expressing $\mu$ and $\delta$-opioid receptor mRNA in the rat hippocampal formation. J Comp Neurol 469:107-118. CrossRef Medline

Sumien N, Chaudhari K, Sidhu A, Forster MJ (2013) Does phytoestrogen supplementation affect cognition differentially in males and females? Brain Res 1514:123-127. CrossRef Medline

Swanson LW (1992) Brain maps: structure of the rat brain. Amsterdam: Elsevier.

Tabatadze N, Smejkalova T, Woolley CS (2013) Distribution and posttranslational modification of synaptic ER $\alpha$ in the adult female rat hippocampus. Endocrinology 154:819-830. CrossRef Medline

Teyler TJ, Vardaris RM, Lewis D, Rawitch AB (1980) Gonadal steroids: effects on excitability of hippocampal pyramidal cells. Science 209:10171018. CrossRef Medline

Thureson-Klein AK, Klein RL (1990) Exocytosis from neuronal large densecored vesicles. Int Rev Cytol 121:67-126. CrossRef Medline

Torres-Reveron A, Khalid S, Williams TJ, Waters EM, Drake CT, McEwen BS, Milner TA (2008) Ovarian steroids modulate leu-enkephalin levels and target leu-enkephalinergic profiles in the female hippocampal mossy fiber pathway. Brain Res 1232:70-84. CrossRef Medline

Torres-Reveron A, Williams TJ, Chapleau JD, Waters EM, McEwen BS, Drake CT, Milner TA (2009a) Ovarian steroids alter m opioid receptor trafficking in hippocampal parvalbumin GABAergic interneurons. Exp Neurol 219:319-327. CrossRef Medline

Torres-Reveron A, Khalid S, Williams TJ, Waters EM, Jacome L, Luine VN, Drake CT, McEwen BS, Milner TA (2009b) Hippocampal dynorphin immunoreactivity increases in response to gonadal steroids and is positioned for direct modulation by ovarian steroid receptors. Neuroscience 159:204-216. CrossRef Medline

Ul Haq R, Liotta A, Kovacs R, Rösler A, Jarosch MJ, Heinemann U, Behrens CJ (2012) Adrenergic modulation of sharp wave-ripple activity in rat hippocampal slices. Hippocampus 22:516-533. CrossRef Medline
Unterwald EM, Knapp C, Zukin RS (1991) Neuroanatomical localization of $k_{1}$ and $\mathrm{k}_{2}$ opioid receptors in rat and guinea pig brain. Brain res 562:57-65. CrossRef Medline

Velísková J (2006) The role of estrogens in seizures and epilepsy: the bad guys or the good guys? Neuroscience 138:837-844. CrossRef Medline

Velísková J, De Jesus G, Kaur R, Velísek L (2010) Females, their estrogens, and seizures. Epilepsia 51:141-144. CrossRef Medline

Vida I, Frotscher M (2000) A hippocampal interneuron associated with the mossy fiber system. Proc Natl Acad Sci U S A 97:1275-1280. CrossRef Medline

Wang JQ, Mao L, Han JS (1992) Comparison of the antinociceptive effects induced by electroacupuncture and transcutaneous electrical nerve stimulation in the rat. Int J Neurosci 65:117-129. CrossRef Medline

Warren SG, Humphreys AG, Juraska JM, Greenough WT (1995) LTP varies across the estrous cycle: enhanced synaptic plasticity in proestrus rats. Brain Res 703:26-30. CrossRef Medline

Watson GB, Lanthorn TH (1993) Electrophysiological actions of d opioids in CAl of the rat hippocampal slice are mediated by one d receptor subtype. Brain Res 601:129-135. CrossRef Medline

Whim MD, Lloyd PE (1994) Differential regulation of the release of the same peptide transmitters from individual identified motor neurons in culture. J Neurosci 14:4244-4251. Medline

Whim MD, Moss GW (2001) A novel technique that measures peptide secretion on a millisecond timescale reveals rapid changes in release. Neuron 30:37-50. CrossRef Medline

Williams TJ, Torres-Reveron A, Chapleau JD, Milner TA (2011a) Hormonal regulation of $\mathrm{d}$ opioid receptor immunoreactivity in interneurons and pyramidal cells in the rat hippocampus. Neurobiol Learn Mem 95: 206-220. CrossRef Medline

Williams TJ, Mitterling KL, Thompson LI, Torres-Reveron A, Waters EM, McEwen BS, Gore AC, Milner TA (2011b) Age- and hormoneregulation of opioid peptides and synaptic proteins in the rat dorsal hippocampal formation. Brain Res 1379:71-85. CrossRef Medline

Wong M, Moss RL (1992) Long-term and short-term electrophysiological effects of estrogen on the synaptic properties of hippocampal CAl neurons. J Neurosci 12:3217-3225. Medline

Woolley CS (1998) Estrogen-mediated structural and functional synaptic plasticity in the female rat hippocampus. Horm Behav 34:140-148. CrossRef Medline

Xie CW, Lewis DV (1995) Endogenous opioids regulate long-term potentiation of synaptic inhibition in the dentate gyrus of rat hippocampus. J Neurosci 15:3788-3795. Medline

Zhang Z, Pan ZZ (2010) Synaptic mechanism for functional synergism between $\mathrm{d}$ - and $\mu$-opioid receptors. J Neurosci 30:4735-4745. CrossRef Medline

Zucker RS, Regehr WG (2002) Short-term synaptic plasticity. Annu Rev Physiol 64:355-405. CrossRef Medline 